\section{Pacific Northwest}

National Laboratory

Operated by Battelle for the

U.S. Department of Energy

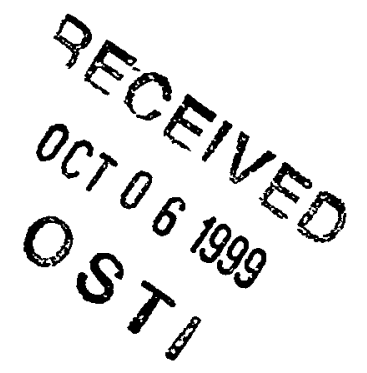

\title{
Drying Results of K-Basin Fuel Element 6603M (Run 5)
}
G. S. Klinger
L. R. Greenwood
B. M. Oliver
P. J. MacFarlan
S. C. Marschman
G. A. Ritter
J. Abrefah

September 1999

Prepared for the U.S. Department of Energy under Contract DE-AC06-76RLO 1830 


\section{DISCLAIMER}

This report was prepared as an account of work sponsored by an agency of the United States Government. Reference herein to any specific commercial product, process, or service by trade name, trademark, manufacturer, or otherwise does not necessarily constitute or imply its endorsement, recommendation, or favoring by the United States Government or any agency thereof, or Battelle Memorial Institute.

\section{PACIFIC NORTHWEST NATIONAL LABORATORY operated by \\ BATTELLE \\ for the \\ UNITED STATES DEPARTMENT OF ENERGY \\ under Contract DE-AC06-76RLO 1830}

Printed in the United-States of America

Available to DOE and DOE contractors from the

Office of Scientific and Technical Information, P.O. Box 62, Oak Ridge, TN 37831; prices available from (615) 576-8401.

Available to the public from the National Technical Information Service, U.S. Department of Commerce, 5285 Port Royal Rd., Springfield, VA 22161 
PNNL-11841

UC-602

\title{
Drying Results of K-Basin Fuel Element 6603M (Run 5)
}

\author{
G. S. Klinger \\ L. R. Greenwood \\ B. M. Oliver \\ P. J. MacFarlan \\ S. C. Marschman \\ G. A. Ritter \\ J. Abrefah
}

September 1999

Prepared for

the U.S. Department of Energy

under Contract DE-AC06-76RLO 1830

Pacific Northwest National Laboratory

Richland, Washington 99352 
•

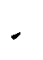




\section{DISCLAIMER}

Portions of this document may be illegible in electronic image products. Images are produced from the best available original document. 


\section{Summary}

An N-Reactor outer fuel element which had been stored under water in the Hanford 100 Area K-West basin was subjected to a combination of low- and high-temperature vacuum drying treatments. These studies are part of a series of tests being conducted by Pacific Northwest National Laboratory on the drying behavior of spent nuclear fuel elements removed from both the $\mathrm{K}$-West and $\mathrm{K}$-East Basins. This report describes the fuel element, the test methodology, and the testing results.

The drying test series was designed to test fuel elements that ranged from intact to severely damaged. The fuel element discussed in this report was removed from K-West canister 6603M in 1996. The element has remained in wet storage in the 327 Postirradiation Testing Laboratory (PTL) since that time. This fuel element had a separated bottom end cap with extensive corrosion on one end. There were spiral cracks at one end causing the breach at that end to open. Small shards of fuel were loosely contained inside the damaged end. While one end was severely damaged, this element had less damage along the length than those tested in Runs 4, 6, 7, and 8 .

The drying test was conducted in the Whole Element Furnace Testing System located in G-cell within the PTL. This test system is composed of three basic systems: the in-cell furnace equipment, the system gas-loop, and the analytical instrument package. The element was subjected to the generalized Interim Process Strategy drying processes which included a hot drying step. The test cycles included:

- Cold Vacuum Drying (CVD) at $\sim 50^{\circ} \mathrm{C}$ under vacuum $(\sim 16 \mathrm{hr})$

- Pressure Rise Tests at $\sim 50^{\circ} \mathrm{C}(\sim 1 \mathrm{hr})$

- Hot Vacuum Drying (HVD) for a total of $\sim 68 \mathrm{hr}\left(\sim 25 \mathrm{hr}\right.$ at $\sim 80^{\circ} \mathrm{C}, \sim 33 \mathrm{hr}$ at $\sim 80^{\circ} \mathrm{C}$ to $\sim 400^{\circ} \mathrm{C}$, and $\sim 10 \mathrm{hr}$ at $\sim 400^{\circ} \mathrm{C}$ )

- System Cooldown to $\sim 50^{\circ} \mathrm{C}(\sim 52 \mathrm{hr})$

- Post-Test Pressure Rise Test at $\sim 50^{\circ} \mathrm{C}(\sim 1 \mathrm{hr})$.

The purpose of the CVD portion of the test was to determine if CVD is successful in removing the majority of the free water from the system in a reasonable length of time. Approximately $4 \mathrm{ml}$ of water were observed in the condenser during the pumpdown phase of CVD (collected in the condenser), in reasonable agreement with that calculated from the water release data over the same time period. An additional $\sim 0.4 \mathrm{mg}$ of water was removed during the post-CVD pressure rise test. This release is likely from free water that was trapped and not completely released during CVD. Comparison of the total pressure and moisture pressure rise from the post-CVD and post-HVD pressure rise tests suggests that other sources of gas are responsible for some of the total pressure rise observed in the post-CVD test. 
During the first segment of $\mathrm{HVD}, \sim 0.9 \mathrm{~g}$ of water was removed at temperatures below $80^{\circ} \mathrm{C}$. The second phase of HVD released $\sim 0.4 \mathrm{~g}$ of water with a single broad peak at $\sim 138^{\circ} \mathrm{C}$. The single broad peak in the moisture release during this phase indicates water release from chemisorbed sites (i.e., hydrated species) at higher temperatures. Unlike Run 3 (and similar to Run 4), thermal decomposition of the hydrated species was not the most significant factor in controlling the removal of water from the system during the HVD. The final phase of $H V D$ at $400^{\circ} \mathrm{C}$ released $\sim 30 \mathrm{mg}$ of water, with an additional $\sim 21 \mathrm{mg}$ of water released during post-HVD cooldown.

The water released after the post-CVD pressure rise test is attributed chiefly to release from regions beneath the cladding and from under the corroded regions. Decomposition of metal oxy-hydrates may also account for some of the release. This fuel element appeared to have a light coating on the cladding which changed color during the test. Water released from the element from isolated regions may be the controlling factor in post-CVD water removal. As observed in previous drying tests, a temperature above $400^{\circ} \mathrm{C}$ may be required for complete drying of the fuel element within a reasonable period of time.

Hydrogen data was obtained from the gas chromatograph during HVD when argon was flowing through the system. Approximately 66 Torr $1(7 \mathrm{mg})$ of hydrogen were released during HVD-1. Hydrogen release during HVD-2 occurred in four major peaks $\left(127^{\circ} \mathrm{C}, \sim 159^{\circ} \mathrm{C}, \sim 253^{\circ} \mathrm{C}\right.$, and $\left.\sim 332^{\circ} \mathrm{C}\right)$, the first of which roughly ( $\sim 14$ Torr $\cdot 1$, or $1.5 \mathrm{mg}$ ) corresponded to a similar water release. The molar quantity of hydrogen released is greater than the water release, which suggests that the water released is quickly reacting with the fuel to produce hydrogen. Fission gases measured during this release support this hypothesis. A broad hydrogen release peak $(\sim 168$ Torr $\cdot 1$, or $18 \mathrm{mg})$ at $\sim 167^{\circ} \mathrm{C}$ is attributed to oxidation of uranium by water vapor, which shows a small increase with time. The next sharp hydrogen release peak $(\sim 61$ Torr $\cdot 1)$ at $\sim 253^{\circ} \mathrm{C}$ is attributed to uranium hydride decomposition. The largest hydrogen release peak ( $\sim 376$ Torr $\cdot 1$, or $41 \mathrm{mg}$ ) was a broad peak centered at $\sim 332^{\circ} \mathrm{C}$ and is attributed to oxidation of uranium metal, possibly from an additional rupture in the cladding, exposing additional uranium surfaces, which may have occurred during the temperature ramp. Above $\sim 400^{\circ} \mathrm{C}$, the level of hydrogen decreased with time, with $\sim 58$ Torr $1(6 \mathrm{mg})$ of hydrogen released during HVD-3. Total hydrogen release during HVD was $\sim 770$ Torr 1 ( $83 \mathrm{mg}$ ). 


\section{Quality Assurance}

This work was conducted under the Quality Assurance Program, Pacific Northwest National Laboratory (PNNL) SNF-70-001, SNF Quality Assurance Program, as implemented by the PNNL SNF Characterization Project Operations Manual. This QA program has been evaluated and determined to effectively implement the requirements of DOE/RW-0333P, Quality Assurance Requirements and Description (QARD). Compliance with the QARD is mandatory for projects that generate data used to support the development of a permanent High-Level Nuclear Waste repository. Further, the U.S.

Department of Energy has determined that the testing activities which generated the results documented in this report shall comply with the QARD. Supporting records for the data in this report are located in the permanent PNNL SNF Characterization Project records, Furnace Testing of SNF Fuel Element $6603 M$. 



\section{Contents}

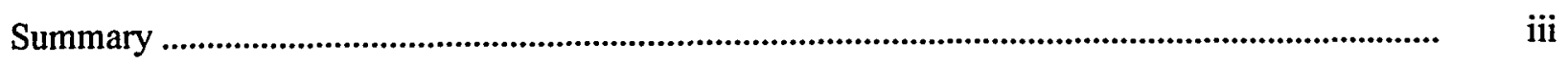

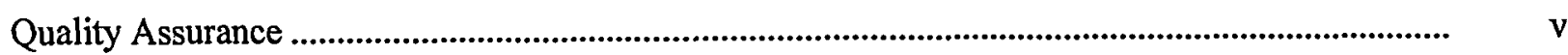

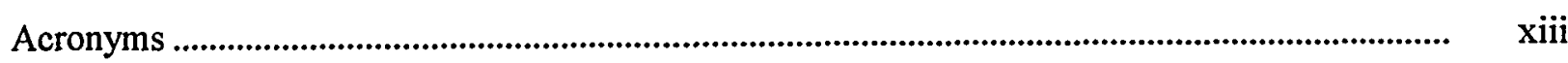

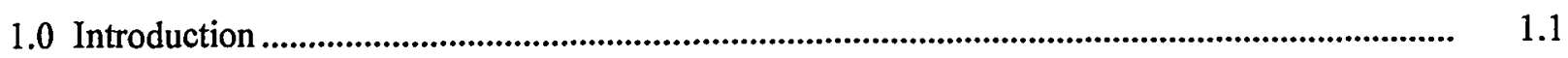

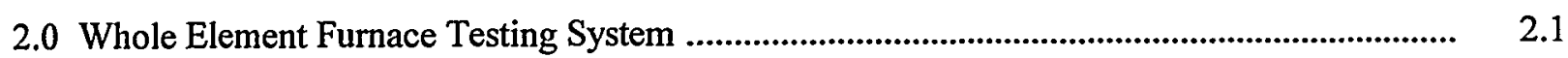

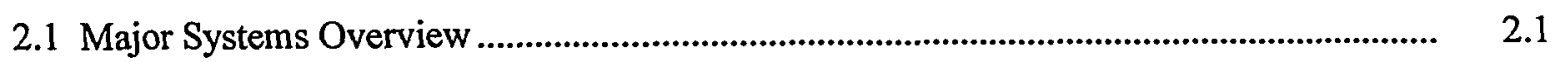

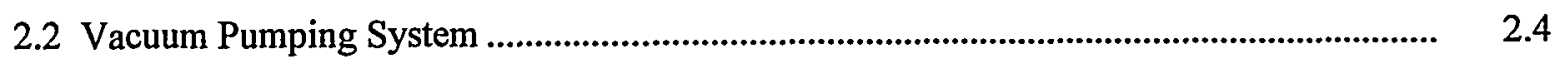

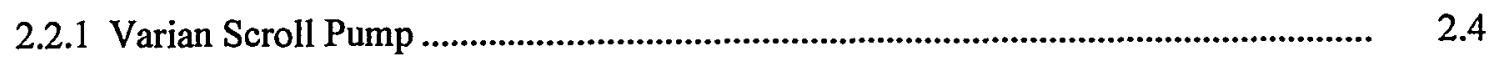

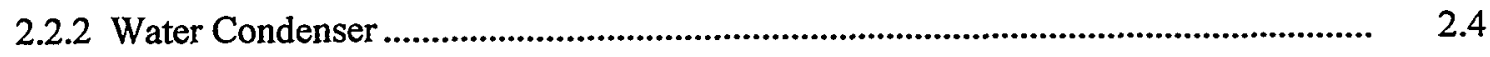

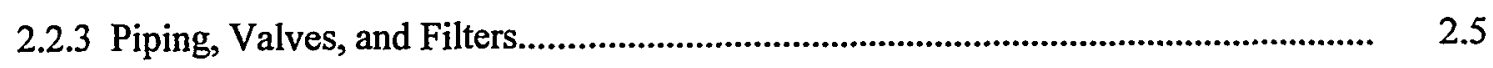

2.2.4 System Line Heaters......................................................................................... 2.5

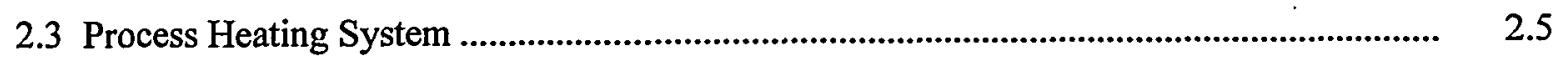

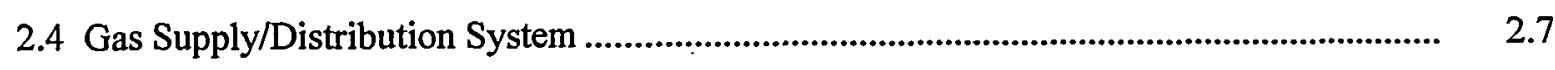

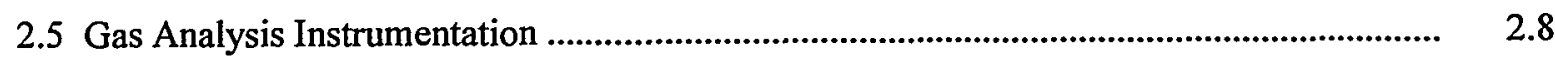

2.5.1 Balzers Omnistar Mass Spectrometer …................................................................ 2.8

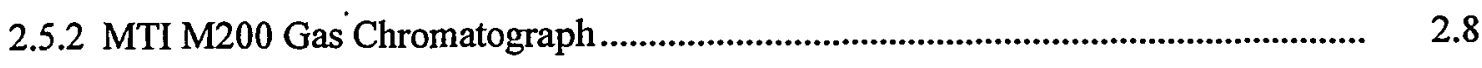

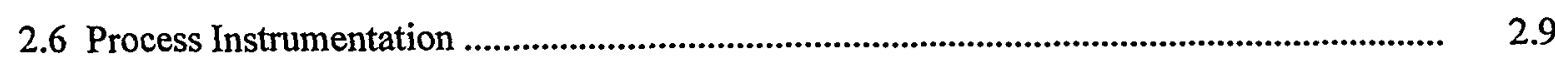

2.6.1 Panametrics Moisture Monitor ................................................................................. 2.9

2.6.2 MKS Baratron Pressure Transducers ................................................................... 2.10

2.6.3 Cole-Parmer Pressure Transducers.......................................................................... 2.11

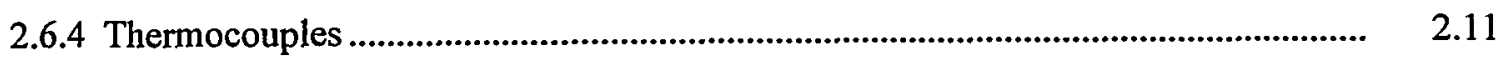

vii 
2.7 Data Acquisition and Control System ..................................................................... 2.11

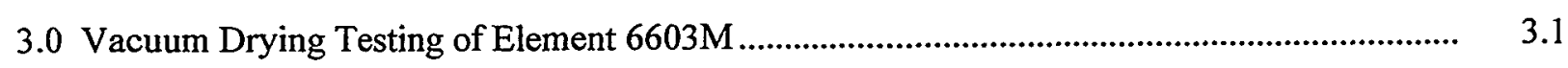

3.1 Fuel Element Transfer and Loading .......................................................................

3.1.1 Pre-Test Visual Inspection ............................................................................. 3.1

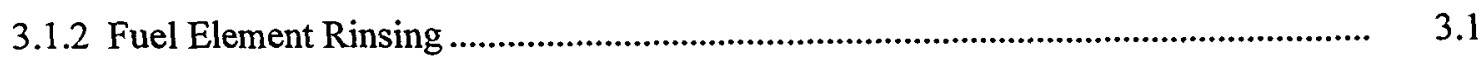

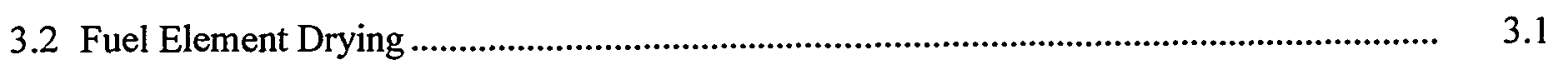

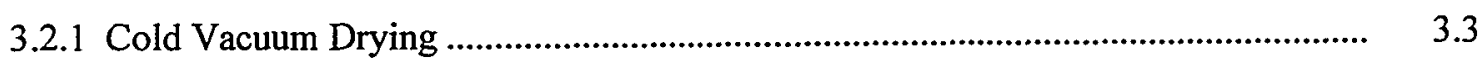

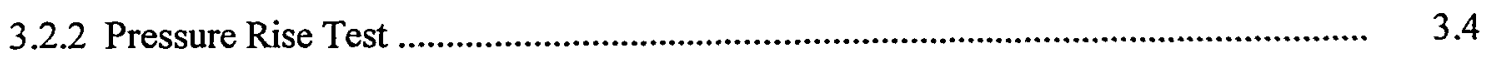

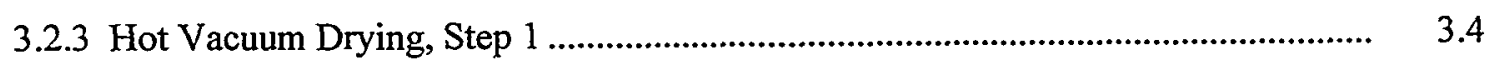

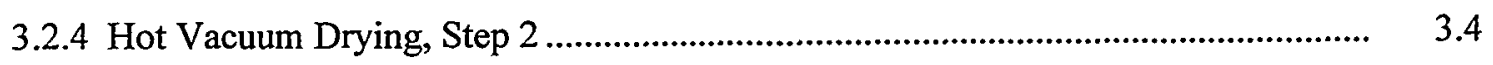

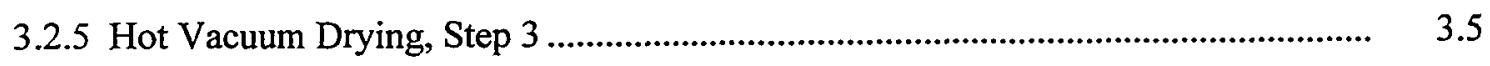

3.2.6 System Cooldown and Post-Test Pressure Rise Test .............................................. 3.5

3.3 Calculation of Water and Hydrogen Inventories .......................................................... 3.5

4.0 Visual Examinations of Element 6603M .......................................................................

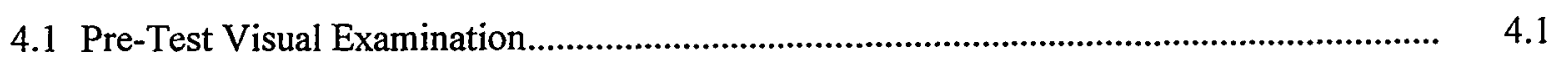

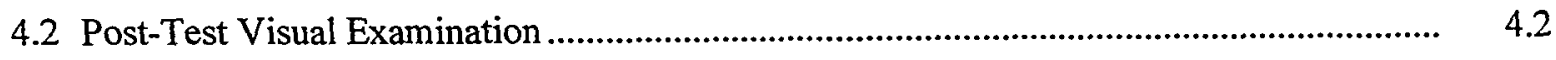

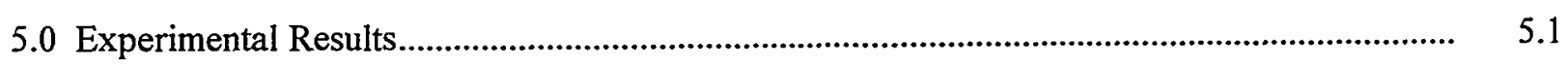

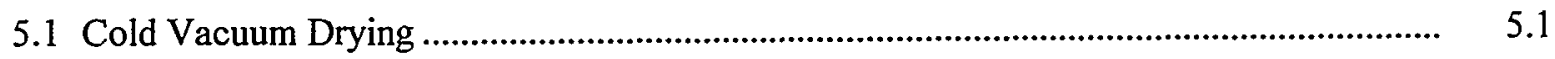

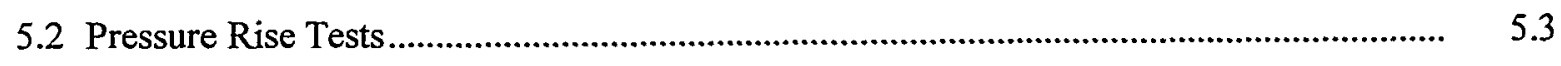

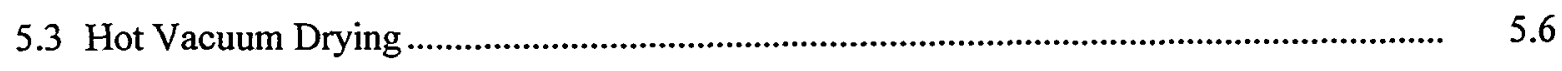

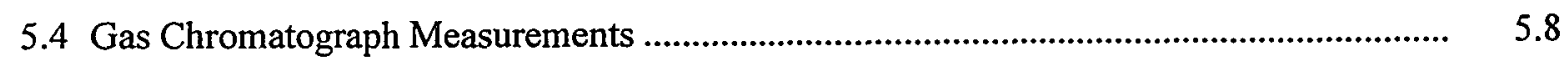

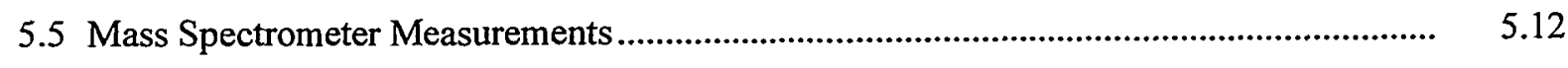

5.5.1 Fission Gas Releases .................................................................................... 5.13

viii 


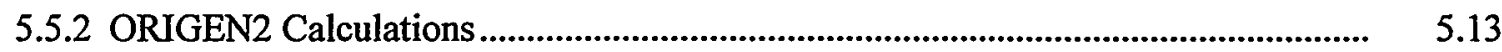

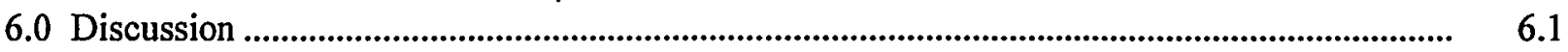

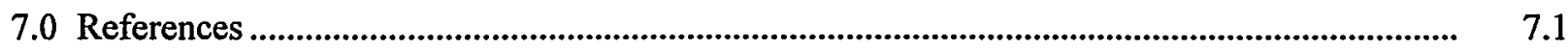

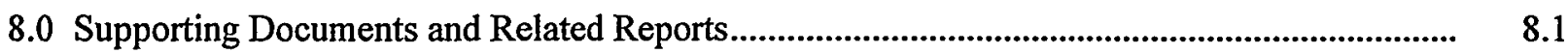





\section{Figures}

2.1 Fuel Element Drying System Components (in-cell) ............................................................ 2.2

2.2 Fuel Element Drying System Components (ex-cell) ........................................................... 2.3

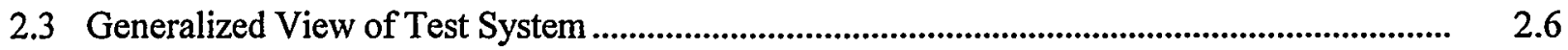

4.1 Two Pre-test Views of the Damaged End of Fuel Element 6603M ....................................

4.2 Pre-test (left) and Post-test (right) Views of the Intact End of Element 6603M.................... 4.2

4.3 Pre-test (left) and Post-test (right) Views of the Damaged End .........................................

4.4 Pre- and Post-test View of a Portion of the Side of Element 6603M..................................

5.1 Drying of SNF Element 6603M, Summary Plot ...........................................................

5.2 Drying of SNF Element 6603M, Cold Vacuum Drying...................................................... 5.4

5.3 Drying of SNF Element 6603M, Post-CVD Pressure Rise Test ......................................... 5.5

5.4 Drying of SNF Element 6603M, Hot Vacuum Drying - Step 1 ............................................. 5.7

5.5 Drying of SNF Element 6603M, Hot Vacuum Drying - Step 2 ........................................ 5.9

5.6 Drying of SNF Element 6603M, Hot Vacuum Drying - Step 3 .......................................... 5.10

5.7 Drying of SNF Element 6603M, Hydrogen Release During HVD and Cooldown ................. 5.11

5.8 Drying of SNF Element 6603M, Normalized Xenon Release During HVD ......................... 5.14

5.9 Concentrations of Krypton and Xenon in Hydrogen Released from Oxidation........................ 5.16

5.10 Drying of SNF Xenon Isotope Release During Post-CVE Pressure Rise Test ......................... 5.18 


\section{Tables}

2.1 Water and Ice Vapor Pressure Data Versus Temperature ................................................... 2.10

3.1 Summary of Nominal Test Design Conditions ….............................................................. 3.2

5.1 Fuel Element 6603M Drying Run Time Line ...............................................................

5.2 Calculated Xenon Isotope Generation in Mark IA and IV N-Reactor Fuel .......................... 5.15 


\section{Acronyms}

$\begin{array}{ll}\text { ATS } & \text { Applied Test Systems } \\ \text { CVD } & \text { Cold Vacuum Drying } \\ \text { DACS } & \text { data acquisition and control system } \\ \text { DP } & \text { dew point } \\ \text { ET } & \text { elapsed time } \\ \text { GC } & \text { gas chromatograph } \\ \text { HP } & \text { Hewlett Packard } \\ \text { HVD } & \text { Hot Vacuum Drying } \\ \text { ID } & \text { inside diameter } \\ \text { IPS } & \text { Integrated Process Strategy } \\ \text { MS } & \text { mass spectrometer } \\ \text { NIST } & \text { National Institute of Standards and Technology } \\ \text { OD } & \text { outside diameter } \\ \text { PNNL } & \text { Pacific Northwest National Laboratory } \\ \text { PTL } & \text { Postirradiation Testing Laboratory } \\ \text { QA } & \text { Quality Assurance } \\ \text { QARD } & \text { Quality Assurance Requirements and Description } \\ \text { SFEC } & \text { single fuel element canister } \\ \text { SNF } & \text { spent nuclear fuel } \\ \text { UHP } & \text { ultra high purity } \\ \text { VP } & \text { vapor pressure }\end{array}$




\subsection{Introduction}

The water-filled K-Basins in the Hanford 100 Area have been used to store N-Reactor spent nuclear fuel (SNF) since the 1970s. An Integrated Process Strategy (IPS) has been developed to package, dry, transport, and store these metallic uranium spent nuclear fuels in an interim storage facility on the Hanford Site (WHC 1995). Information required to support the development of the drying processes, and the required safety analyses, is being obtained from characterization tests conducted on fuel elements removed from the K-Basins. A series of drying tests (reported in separate documents, see Section 8.0) have been conducted by Pacific Northwest National Laboratory (PNNL) ${ }^{(\mathbf{a})}$ on several intact and damaged fuel elements recovered from both the K-East and K-West Basins.

This report documents the results of the fifth of those tests conducted on an N-Reactor outer fuel element $(6603 \mathrm{M})$ which had been stored under water in the Hanford 100 Area K-West basin from 1983 until 1996. This fuel element was subjected to a combination of low- and high-temperature vacuum drying treatments which were intended to mimic, wherever possible, the fuel treatment strategies of the IPS. The system used for the drying test was the Whole Element Furnace Testing System, described in Section 2.0. The test conditions and methodologies are given in Section 3.0. Inspections on the fuel element before and after the test are provided in Section 4.0. The experimental results are provided in Section 5.0. Discussion of the results is given in Section 6.0.

(a) Operated by Battelle for the U.S. Department of Energy under Contract DE-AC06-76RLO 1830. 


\subsection{Whole Element Furnace Testing System}

A complete description for the Whole Element Furnace Testing System, including detailed equipment specifications, is provided in Ritter et al. (1998).

\subsection{Major Systems Overview}

An overview of the furnace testing system is presented in this section. The subsystems pertinent to this test report are as follows:

- Vacuum Pumping System - This system consists of a scroll-type vacuum pump, a condenser with chiller, filters, valves, and piping, which provide the vacuum pressures and flows required for the proposed IPS vacuum processes.

- Process Heating System - This system consists of a resistively heated clam-shell furnace and sample chamber (retort) to provide heating to the fuel element and to control process temperatures.

- Gas Supply/Distribution System - This system consists of gas bottles; mass flow controllers; piping; and valves for metering argon, air, or oxygen through the system. A bubbler is also available for adding water vapor to the system if desired.

- Gas Analysis Instrumentation - The gas analysis instrumentation includes a 300-amu quadrupole mass spectrometer (MS) and a gas chromatograph (GC) for monitoring selected elements in the process gas stream.

- Process Instrumentation - The system is equipped with several instruments for measuring process temperatures, pressures, and moisture level. An auxiliary turbo vacuum pumping system provides low system pressures for zero adjustment of the high accuracy retort pressure sensor.

- Data Acquisition and Control System (DACS) - The DACS consists of an IBM-compatible computer and data acquisition/control unit to monitor/store key system parameters (temperatures, pressures, flows, moisture level) along with controlling the process heating system and safety argon system.

Figures 2.1 and 2.2 are photographs of the equipment located inside and outside of G-Cell. The furnace (including retort) and some of the process piping, instrumentation, and valves are located inside the hot cell. The furnace sits on the cell floor and the process piping is routed to a rack that hangs on the west cell wall. Process piping, electrical power, and instrumentation wires pass through several split plugs on the west side of the cell. The process piping on the outside of the cell is contained within a glove bag, which provides a secondary containment as a precaution in case the process piping lines become contaminated. The vacuum pump, condenser, bubbler, GC, and the remainder of the 


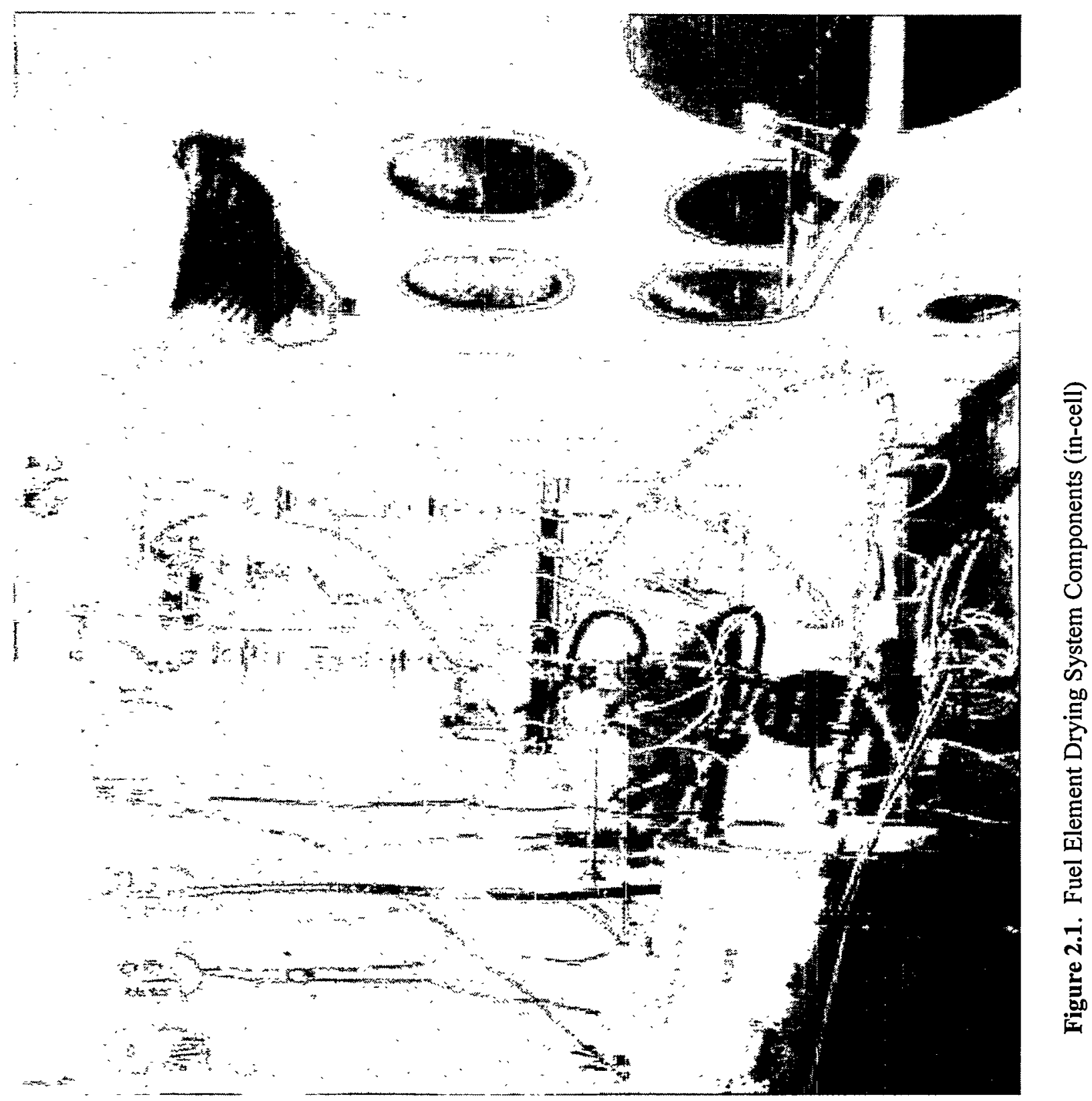

instrumentation and valves are located inside this glove bag. Instrumentation and electrical power wires are routed through pass-through sleeves on the sides of the glove bag to the instrument rack and computer console.

The instrument rack contains the readout/control units for the pressure sensors, moisture sensor, and flow controllers, along with the heat trace temperature controllers, data acquisition/control unit, turbo pump controller, GC laptop computer, and uninterruptable power supplies. The computers for the DACS and MS are located next to the instrument rack. The following sections provide more detailed descriptions of the components for these subsystems. 


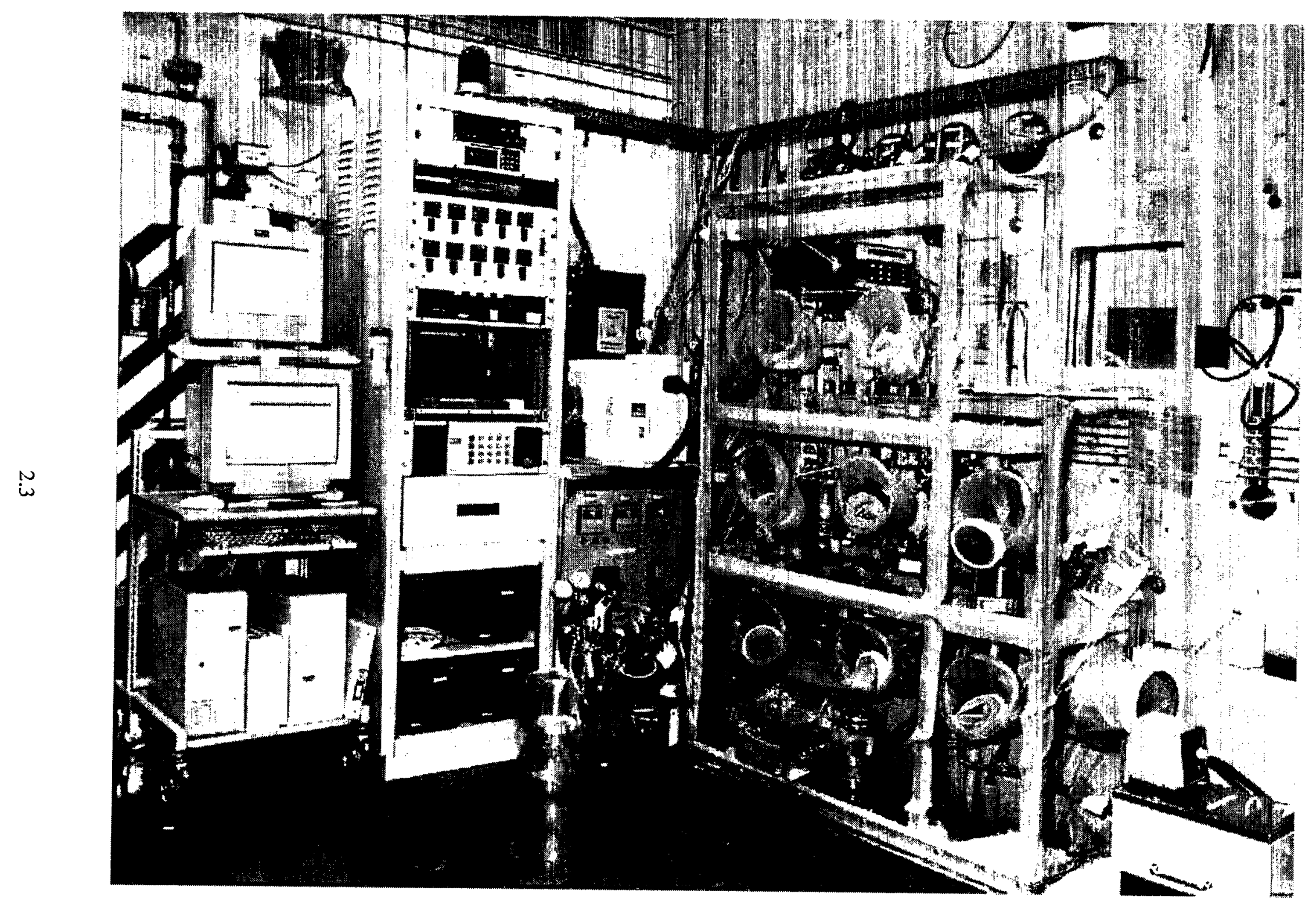

Figure 2.2. Fuel Element Drying System Components (ex-cell) 
instrumentation and valves are located inside this glove bag. Instrumentation and electrical power wires are routed through pass-through sleeves on the sides of the glove bag to the instrument rack and computer console.

The instrument rack contains the readout/control units for the pressure sensors, moisture sensor, and flow controllers, along with the heat trace temperature controllers, data acquisition/control unit, turbo pump controller, GC laptop computer, and uninterruptable power supplies. The computers for the DACS and MS are located next to the instrument rack. The following sections provide more detailed descriptions of the components for these subsystems.

\subsection{Vacuum Pumping System}

The vacuum pumping system provides the pressures and flows required for the proposed IPS processes. This system connects the furnace retort with all the other components of the test system through various valves, fittings, and piping. The vacuum pumping system consists of the following components:

- scroll pump for evacuating the system to pressures below 1 Torr

- water condenser with refrigerated chiller for gross removal of water

- valves and piping for connecting the various components and controlling the flow direction

- particulate filters to prevent the spread of contamination

- heating cords with temperature controllers for preventing condensation in lines.

\subsubsection{Varian Scroll Pump}

The system vacuum pump is a Varian model 300DS scroll pump. This pump has an ultimate vacuum pressure less than $10^{-2}$ Torr and a peak pumping speed of $250 \mathrm{l} / \mathrm{min}(8.8 \mathrm{cfm})$. These pressures and flows are more than adequate for simulating the conditions of the proposed IPS vacuum processes. For a single fuel element, this amount of flow may be more than desired. Therefore, a metering valve was installed on the pump inlet to throttle the flow to lower levels as required. The desired system pressure is achieved by either using the metering valve or flowing ultra high purity (UHP) argon into the system through the entire gas loop or via a direct injection of ballast gas at the pump inlet. The use of argon gas helps to prevent the in-leakage of moisture-containing air through small system leaks (which are difficult to eliminate) that would interfere with process monitoring equipment.

\subsubsection{Water Condenser}

The scroll vacuum pump can be damaged by condensation of liquid water in the scroll mechanism, and, since each element was wet at the start of each test, the possibility of pump damage was considered. 
A water condenser with corresponding chiller was installed in the system to condense the bulk of the water before it reaches the pump. This condenser can be valved into the system in series with the scroll vacuum pump or can be bypassed if not needed. The condenser cannot trap all the liberated free water, but is efficient at removing the majority of free water in the system. The condenser is used only during the first phase of Cold Vacuum Drying (CVD). The condenser was custom fabricated specifically for this system. Detailed sketches and specifications for the condenser are given in Ritter et al. (1998).

\subsubsection{Piping, Valves, and Filters}

The vacuum pumping system connects the system components through various valves, fittings, and piping. A simplified piping schematic for the system is shown in Figure 2.3. This schematic shows the basic flow path of gases through the system that was used for this test, along with the relative locations of the major components, valves, and instruments. Detailed system piping diagrams are provided in Ritter et al. (1998) along with approximate lengths for the piping lines. As seen in Figure 2.3, there are numerous valves in the system that are used to direct the flow to and from the various components. Most of the valves in the system are ball valves and range from $1 / 4$ in. to $1 / 2$ in. nominal size. The system piping is constructed of thin wall tubing (1/4 in. to $1 / 2 \mathrm{in.} \mathrm{OD)} \mathrm{and} \mathrm{is} \mathrm{typically} \mathrm{connected} \mathrm{using} \mathrm{simple} \mathrm{Swagelok}$ fittings (tees, elbows, unions, etc.). Ports for gas sampling/analysis and monitoring of system pressure, temperature, and humidity are also provided at key locations in the system piping. Special fittings and pipe-threaded fittings are used in some locations for connecting piping to the process instruments.

Particulate filters are installed in the system on both the inlet and outlet to the retort to help prevent the spread of contamination to the system piping on the outside of the hot cell. These filters are constructed of a microporous fiberglass media in a stainless steel housing. They are $99.9 \%$ efficient for particulates that are 0.2 microns and larger in size. Two different size filters, manufactured by Matheson, are used in the system.

\subsubsection{System Line Heaters}

All of the stainless steel tubing that carries gases into the furnace retort and resultant gases from the retort is heated to about $75^{\circ} \mathrm{C}$ to ensure condensable water vapor remains in the gas phase. Simple heat "cords" capable of being wrapped upon each other (as required at tees, elbows, and other connections) were found to be a good heating method for this system. The heating cords are controlled by simple proportional controllers. Type-K thermocouples are installed on each heated line so that the DACS can monitor and record the temperature.

\subsection{Process Heating System}

The whole element furnace is a 4-ft-long resistively heated clam-shell furnace. The furnace, a Series 3210 supplied by Applied Test Systems (ATS), has a temperature rating of $900^{\circ} \mathrm{C}$ and total heating capacity of $13,800 \mathrm{~W}$. The internal dimensions are $5 \mathrm{in}$. ID by $45 \mathrm{in}$. long. The furnace has three separate sets of heating elements that allow the heating to be controlled in zones; each zone is 15 in. long and supplies up to $4600 \mathrm{~W}$ heating. The zones can be controlled separately to establish a flat temperature profile within the furnace, even though heat is lost preferentially out the end with the retort entry flange. 


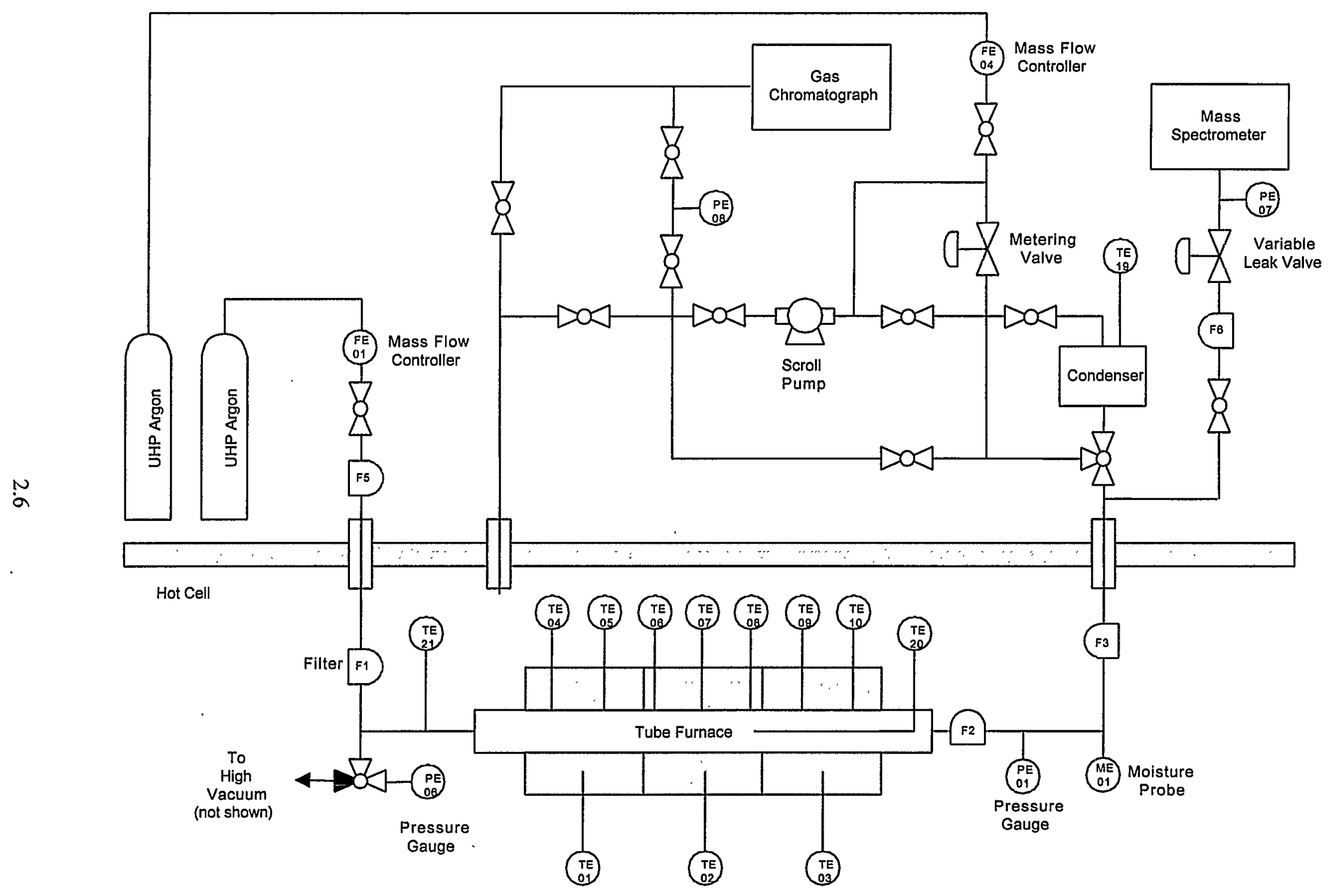

Figure 2.3. Generalized View of Test System 
A heat reflector consisting of several thin Inconel plates is used to reduce heat loss from the flange end of the retort. The furnace controller is an ATS Series 3000, which consists of three programmable, selftuning proportional with integral and derivative controllers. These controllers are also interfaced to the DACS, which is capable of providing limited input to the controllers as required.

The retort, an ATS Series 3910, is an Inconel tube fitted with a gas inlet tube at one end and a gasketed flange at the other. Of all high-temperature materials, Inconel series 600 was selected to reduce the amount of oxidation and water pickup by the retort and associated components. Experience has shown that stainless steel components were easily affected by corrosion, which could then affect test results. The body of the retort is fabricated from schedule 40 Inconel pipe ( $4.5 \mathrm{in.} \mathrm{OD,} 4.026 \mathrm{in}$. ID), and the inside length is about $44.5 \mathrm{in}$. Seven type-K thermocouples are installed equidistant along one side of the retort and extend into the retort interior approximately $1 / 8 \mathrm{in}$. These thermocouples are used to monitor the retort temperature so that if a reaction with the fuel element occurs (which would locally raise the retort temperature), this event can be correlated with the approximate location on the fuel.

An Inconel sample/transfer boat is used to load the fuel element into the furnace. The boat is fabricated from an 11-gauge (0.120-in.-thick) Inconel 601 sheet, which is formed into a flattened u-shape. The boat has a weir and a swivel handle on each end. The weirs are used to keep free water or particulates contained in the boat as required.

\subsection{Gas Supply/Distribution System}

The gas supply system and vacuum pumping system together are capable of controlling the fuel element environment to vacuum or moderate pressure conditions, and/or exposing the fuel element to a variety of gases or gas mixtures. The gas loop is typically operated as a single-pass system with no capability for recirculation. The gás supply system consists of gas bottles; mass flow controllers; piping; and valves for metering argon, air, or oxygen through the system. A bubbler is also available for adding water vapor to the process gas stream as required, but it was not used in these.tests.

The gas supply system contains three Matheson mass flow controllers calibrated for argon, air, and oxygen. All gases are typically specified "ultra high purity" and are additionally filtered for water using molecular sieve columns. Argon is the principal inert gas used, as it is more dense than air, provides reasonable thermal conductivity, and requires simpler handling procedures than lighter gases such as helium. The argon purge gas is introduced into the retort through FE-01, which is a Matheson model 8272-0422 oxygen controller, recalibrated for argon gas at $25^{\circ} \mathrm{C}$ using a NIST-traceable bubble flow meter. Air and oxygen are not currently used because any oxidative steps have been deleted from the current IPS for the SNF. The manufacturer's specifications for the air and oxygen controllers' flow rate ranges are $0-280 \mathrm{sccm}$ argon, $0-1000 \mathrm{sccm}$ air, and $0-10 \mathrm{sccm}$ oxygen. If higher flow rates are desired, a new mass flow controller with a higher range could be procured and installed in the system. 


\subsection{Gas Analysis Instrumentation}

\subsubsection{Balzers Omnistar Mass Spectrometer}

The Balzers Omnistar MS is a compact, computer-controlled, quadrupole MS capable of scanning to $300 \mathrm{amu}$. The unit is capable of monitoring up to 64 components within a gas stream with a nominal detection limit of less than $1 \mathrm{ppm}$ for most gases other than hydrogen. The MS was used to monitor hydrogen, nitrogen (for air in-leakage), krypton, xenon, and other elements during the test.

The MS was modified as a result of early system testing and calibration to improve the time response to small changes in hydrogen pressure. Before testing, the MS was calibrated for hydrogen using mixtures of hydrogen and helium, and hydrogen and argon gas. The residence time of each gas could be measured in the quadrupole chamber, and it was observed that the hydrogen decay time was approximately four times as long as helium. This was not unexpected as turbomolecular pumps have a lower pumping efficiency for very light gases. In standard practice this is acceptable, but for these tests, where determining hydrogen could be very important, steps were taken to improve the hydrogen decay time. The MS vacuum system was modified by adding a stainless steel flanged tee, a gate valve, and a room-temperature hydrogen getter downstream from the quadrupole. Under vacuum the gate valve can be opened, exposing the getter to the system to help scavenge hydrogen from the system following analysis. This modification reduced the residence time of hydrogen in the system substantially, and decreased the background level of hydrogen by about a factor of 2 . The getter improved the system response to transient events that might result in the release of hydrogen.

A Granville-Phillips variable leak valve, series 203, was added to the gas sampling inlet of the MS in order to permit operation over a wide range of system pressures. Without the leak valve, system pressures above about 40 Torr produce too much flow through the MS capillary tube, which overwhelms the turbo pump used to pump down the MS vacuum chamber. Flow through the leak valve can be continuously varied from $0.4 \mathrm{l} / \mathrm{s}$ to $10^{-11} \mathrm{l} / \mathrm{s}$, which allows the MS inlet pressure to be controlled to any pressure desired, even if the system pressure varies dramatically. The pressure on the low-pressure side of the leak valve is measured using a Cole-Parmer sensor (PE-07) and recorded by the DACS. The inlet head pressure is divided by the pressure used for the calibration, and this factor is applied to the test data for calculating actual gas concentrations. The MS was calibrated at $\sim 30$ Torr head pressure with a certified gas standard consisting of $1050 \mathrm{ppmv}$ hydrogen in argon.

\subsubsection{MTI M200 Gas Chromatograph}

The MTI M200 Gas Chromatograph is a high-speed GC that is used to monitor the quantities of hydrogen and other light gases in the furnace testing system gas loop. This instrument is interfaced with a laptop computer to record data. The GC is designed to operate at near-atmospheric pressure; thus it may be configured in two different ways for measurement purposes. At system pressures near atmospheric, the GC is configured to sample directly from the gas loop ahead of the system vacuum pump. When the system is under vacuum, the GC is configured to sample from the exhaust side of the vacuum pump. The gas output from the pump is sufficiently compressed that the GC can sample and analyze this gas. The GC inlet pressure is measured using a Cole-Parmer pressure sensor (PE-08) and recorded by the DACS. 
No correction for the difference in the sample pressure and calibration pressure is applied, since both are $\sim 760$ Torr $(1 \mathrm{~atm})$. The GC was calibrated with a certified gas standard consisting of $1050 \mathrm{ppmv}$ hydrogen in argon.

\subsection{Process Instrumentation}

The furnace testing system contains several process instruments for monitoring moisture content, pressure, and temperature. The key instruments are as follows:

- Panametrics moisture monitor

- MKS Baratron pressure transducers

- Cole-Parmer pressure transducers

- Type-K thermocouples.

\subsubsection{Panametrics Moisture Monitor}

The Panametrics moisture monitor model MMS35 uses a solid electrochemical probe (model M2L) that measures moisture by measuring the characteristic capacitance of the probe as a function of the moisture in the gas phase. The sensor has a nominal dew point range of $-110^{\circ} \mathrm{C}$ to $20^{\circ} \mathrm{C}$. Previous testing indicated that contamination causes the probe to lose calibration and results in moisture readings that drift with time. To prevent contamination of the probe tip, the probe is installed in the gas loop downstream of two glass particulate filters. Further, the probes are changed following each test and surveyed for radioactive contamination. If no contamination is found, and the data correlate well with the data obtained from the MS, the readings are accepted.

A calibration verification procedure can be performed using calibrated water "leak" tubes. These tubes can be placed inside the furnace and, when heated, will establish a known water vapor pressure in the system. However, this procedure is time intensive; approximately 2 weeks are required to calibrate one probe over the range of moisture likely to be encountered in these tests. This procedure is used only if the moisture monitor results vary widely from the MS data.

Output of the moisture monitor is in dew point (dp) in degrees Celsius. For comparison with other test data, these DP values were converted to water vapor pressure in Torr using the water and ice vapor pressure data shown in Table 2.1. Interpolation of the data was accomplished using a 6th-order polynomial fit to the log of the vapor pressure versus temperature data. The resulting conversion expression is as follows: 
Table 2.1. Water and Ice Vapor Pressure Data Versus Temperature

\begin{tabular}{|c|c|c|c|}
\hline \multirow{2}{*}{$\begin{array}{c}\text { Dew Point } \\
\left({ }^{\circ} \mathbf{C}\right)\end{array}$} & \multicolumn{3}{|c|}{ Vapor Pressure (VP) } \\
\cline { 2 - 4 }$\left(\mathbf{( P a}^{\text {(a) }}\right.$ & (Torr) & Log (Torr) \\
-80 & $5.500 \mathrm{E}-02$ & $4.126 \mathrm{E}-04$ & $-3.385 \mathrm{E}+00$ \\
-75 & $1.220 \mathrm{E}-01$ & $9.151 \mathrm{E}-04$ & $-3.039 \mathrm{E}+00$ \\
-70 & $2.610 \mathrm{E}-01$ & $1.958 \mathrm{E}-03$ & $-2.708 \mathrm{E}+00$ \\
-65 & $5.400 \mathrm{E}-01$ & $4.051 \mathrm{E}-03$ & $-2.392 \mathrm{E}+00$ \\
-60 & $1.080 \mathrm{E}+00$ & $8.101 \mathrm{E}-03$ & $-2.091 \mathrm{E}+00$ \\
-55 & $2.093 \mathrm{E}+00$ & $1.570 \mathrm{E}-02$ & $-1.804 \mathrm{E}+00$ \\
-50 & $3.936 \mathrm{E}+00$ & $2.952 \mathrm{E}-02$ & $-1.530 \mathrm{E}+00$ \\
-45 & $7.202 \mathrm{E}+00$ & $5.402 \mathrm{E}-02$ & $-1.267 \mathrm{E}+00$ \\
-40 & $1.284 \mathrm{E}+01$ & $9.631 \mathrm{E}-02$ & $-1.016 \mathrm{E}+00$ \\
-35 & $2.235 \mathrm{E}+01$ & $1.676 \mathrm{E}-01$ & $-7.756 \mathrm{E}-01$ \\
-30 & $3.801 \mathrm{E}+01$ & $2.851 \mathrm{E}-01$ & $-5.450 \mathrm{E}-01$ \\
-25 & $6.329 \mathrm{E}+01$ & $4.747 \mathrm{E}-01$ & $-3.235 \mathrm{E}-01$ \\
-20 & $1.033 \mathrm{E}+02$ & $7.746 \mathrm{E}-01$ & $-1.109 \mathrm{E}-01$ \\
-15 & $1.653 \mathrm{E}+02$ & $1.240 \mathrm{E}+00$ & $9.339 \mathrm{E}-02$ \\
-10 & $2.599 \mathrm{E}+02$ & $1.950 \mathrm{E}+00$ & $2.899 \mathrm{E}-01$ \\
-5 & $4.018 \mathrm{E}+02$ & $3.014 \mathrm{E}+00$ & $4.791 \mathrm{E}-01$ \\
0 & $6.113 \mathrm{E}+02$ & $4.585 \mathrm{E}+00$ & $6.614 \mathrm{E}-01$ \\
10 & $1.228 \mathrm{E}+03$ & $9.212 \mathrm{E}+00$ & $9.644 \mathrm{E}-01$ \\
\hline
\end{tabular}

$$
\mathrm{VP}(\text { Torr })=\log ^{-1}\left[\mathrm{C}_{1} \cdot \mathrm{DP}^{6}+\mathrm{C}_{2} \cdot \mathrm{DP}^{5}+\mathrm{C}_{3} \cdot \mathrm{DP}^{4}+\mathrm{C}_{4} \cdot \mathrm{DP}^{3}+\mathrm{C}_{5} \cdot \mathrm{DP}^{2}+\mathrm{C}_{6} \cdot \mathrm{DP}+\mathrm{C}_{7}\right]
$$

where $C_{1}=-6.7260 \mathrm{E}-12$

$\mathrm{C}_{2}=-1.7250 \mathrm{E}-09$

$\mathrm{C}_{3}=-1.7089 \mathrm{E}-07$

$\mathrm{C}_{4}=-7.2618 \mathrm{E}-06$

$\mathrm{C}_{5}=-2.9668 \mathrm{E}-04$

$\mathrm{C}_{6}=3.4414 \mathrm{E}-02$

$\mathrm{C}_{7}=6.5933 \mathrm{E}-01$

\subsubsection{MKS Baratron Pressure Transducers}

Two MKS Baratron model 690 calibrated pressure transducers coupled with MKS model 270 signal conditioners are used as the primary measurement for the overall system pressure. As shown in Figure 2.3, PE-0 1 measures the system pressure downstream of the retort outlet, whereas PE-06 measures the system pressure at the retort inlet. PE-01 indicates pressure in the range of 0.1 Torr to 10,000 Torr. The pressure range of PE-06 is 0.01 Torr to 1000 Torr. PE-06 was installed after the first two fuel element drying tests to provide more accurate measurements than PE-01 for low pressures. PE-06 is therefore considered the primary system pressure measurement. In addition, the 270 signal conditioner 
procured with PE-06 has a special capability to remotely zero the transducer, which provides more accurate pressure measurements below 1 Torr.

An auxiliary high vacuum turbo pump is used to evacuate the inlet to PE- 06 to well below $10^{-4}$ Torr, so that the transducer can be accurately re-zeroed. The 270 signal conditioner used with PE-01 does not have a remote zeroing capability. Both signal conditioners have analog outputs that are interfaced to the DACS so that system pressure is continuously recorded.

\subsubsection{Cole-Parmer Pressure Transducers}

Two Cole-Parmer model H-68801-53 calibrated diaphragm pressure transducers are installed on the MS and GC sample lines as indicated by PE-07 and PE-08 in Figure 2.3. These pressure measurements are used to normalize the MS and GC data so that actual gas concentrations in the system can be calculated from the relative concentrations measured. These sensors have a range of 0 to 1500 Torr with a resolution of 0.1 Torr, and an accuracy of $\pm 1 \%$ or \pm 1 Torr, whichever is larger. Both readout units (model H-68801-03) have analog outputs that are interfaced to the DACS so that these pressures are continuously recorded.

\subsubsection{Thermocouples}

Thermocouples provide a simple, reliable method for measuring system temperatures. As shown in Figure 2.3, over 20 thermocouples are installed at various locations in the system to provide key temperature measurements. The retort temperatures are of primary importance, and these temperatures are measured by thermocouples TE- 04 through TE-10, which are positioned equidistant along the length of the retort. Other key temperature measurements include the retort center temperature (TE-20, which is a 30-in.-long thermocouple installed through the outlet end of the retort); retort inlet temperature (TE-21); condenser gas temperature (TE-19); and the condenser coolant temperature (TE-22). Thermocouples TE11 through TE-17 are used for controlling the temperature of the heated lines. All thermocouple readings are continuously recorded using the DACS.

\subsection{Data Acquisition and Control System}

The DACS monitors system parameters and controls the furnace and safety argon system. The DACS consists of a Hewlett Packard (HP) 3497A data acquisition/control unit and an IBM-compatible computer. A National Instruments general purpose interface bus card, installed in the IBM-compatible computer, is used to communicate with the HP 3497A. The computer communicates with the furnace temperature controllers over serial port 0 using an RS-232/RS-485 converter. The DACS uses National Instruments LabView for Windows as the control software.

The DACS is designed to measure critical system parameters during fuel conditioning tests, including temperatures, pressures, flow rates, and moisture level. The measured parameters are converted to engineering units, displayed on the computer screen, and stored to disk at user-defined intervals. The data files are stored in a tab-delimited format to allow importing into a standard spreadsheet or plotting program. A plotting screen also allows for plotting of up to six parameters at a time. 
Limited control of the furnace can be performed with the DACS. Each of the three furnace zone temperatures can be remotely set by the DACS. In addition, the DACS allows the operator to start and stop the furnace and select one of four temperature profiles that are pre-programmed in the furnace temperature controllers. Note that these profiles must be programmed manually in the furnace controllers before using the DACS to select them. 


\subsection{Vacuum Drying Testing of Element 6603M}

The drying test was performed in accordance with Test Procedure, Furnace Testing of N-Reactor Fuel Element 6603M, PTL-106, Revision 0. This document is located in the PNNL permanent project records for this test.

The testing consisted of three parts.(discussed in this section):

- removing the fuel from its shipping canister, performing a visual inspection, loading the fuel onto the furnace system sample boat, and transferring it to the PTL G-Cell for loading into the furnace

- drying the fuel element using a combination of Cold Vacuum Drying (CVD) and Hot Vacuum Drying (HVD) processes

- unloading the furnace, performing a post-test visual inspection, and returning the fuel element to its shipping canister.

\subsection{Fuel Element Transfer and Loading}

\subsubsection{Pre-Test Visual Inspection}

The pre-test visual inspection was conducted using a high-resolution color $\mathrm{CCD}$ video camera located inside the PTL F-Cell (adjacent to the G-Cell) where the sample was unloaded from the shipping canister and visually inspected. The results were recorded using a Panasonic Super-VHS resolution video recorder. This examination was conducted to document the condition of the fuel element prior to the test and to determine if any changes had occurred since it was removed from the $\mathrm{K}$-West Basin and shipped to the PTL. The results of this inspection are presented in Section 4.0.

\subsubsection{Fuél Element Rinsing}

Fuel element $6603 \mathrm{M}$ had been stored in the PTL water storage pool contained in a single fuel element canister (SFEC) that was filled with K-Basin water. Before the start of the drying test, the element was rinsed in F-Cell. This rinsing involved raising and lowering the element several times in the SFEC using one of the cell's manipulators. Following rinsing, the element was transferred to G-Cell for loading into the element test retort.

\subsection{Fuel Element Drying}

The fuel element was subjected to cold and hot vacuum drying. The drying test was conducted in six phases: 
1. Cold Vacuum Drying

2. Pressure Rise Test

3. Hot Vacuum Drying (first step)
4. Hot Vacuum Drying (second step)

5. Hot Vacuum Drying (third step)

6. Post-Test Pressure Rise Test

The nominal design conditions used for these test phases are summarized in Table 3.1. Each phase is discussed below.

Table 3.1. Summary of Nominal Test Design Conditions

\begin{tabular}{|c|c|}
\hline Test Segment & Nominal Test Condition $^{(2)}$ \\
\hline $\begin{array}{l}\text { A. Cold Vacuum Drying } \\
\text { System Configuration } \\
\text { Test Temperature, }{ }^{\circ} \mathrm{C} \\
\text { Atmosphere } \\
\text { Pressure, Torr } \\
\text { Gas Flow Rate, cc/min } \\
\text { Gas Species Monitored } \\
\text { Duration, hr }\end{array}$ & $\begin{array}{c}\text { Pump on, }{ }^{(b)} \text { argon gas flow during initial condenser pumpdown phase } \\
50 \\
\text { Ar background, Vacuum } \\
\sim 70,<5 \\
0 \\
\mathrm{H}_{2}, \mathrm{H}_{2} \mathrm{O}, \mathrm{N}_{2}, \mathrm{O}_{2}, \mathrm{CO}_{2}, \mathrm{Ar}, \mathrm{Kr}, \mathrm{Xe} \\
\text { CVD is conducted until the total pressure in the retort falls below } 0.5 \text { Torr }\end{array}$ \\
\hline $\begin{array}{l}\text { B. Pressure Rise Test } \\
\text { System Configuration } \\
\text { Test Temperature, }{ }^{\circ} \mathrm{C} \\
\text { Atmosphere } \\
\text { Initial Pressure, Torr } \\
\text { Gas Flow Rate, cc/min } \\
\text { Gas Species Monitored } \\
\text { Pressure Rise (acceptable level, Torr) } \\
\text { Duration, hr }\end{array}$ & $\begin{array}{c}\text { Test Chamber Isolated } \\
50 \\
\text { Vacuum } \\
<5 \\
0 \\
\mathrm{H}_{2}, \mathrm{H}_{2} \mathrm{O}, \mathrm{N}_{2}, \mathrm{O}_{2,} \mathrm{CO}_{2}, \mathrm{Ar}, \mathrm{Kr}, \mathrm{Xe} \\
<0.5 \\
1\end{array}$ \\
\hline $\begin{array}{l}\text { C. Hot Vacuum Drying (Step 1) } \\
\text { System Configuration } \\
\text { Test Temperature Range, }{ }^{\circ} \mathrm{C} \\
\text { Atmosphere } \\
\text { Pressure, Torr } \\
\text { Gas Flow Rate, cc/min } \\
\text { Gas Species Monitored } \\
\text { Duration, hr }\end{array}$ & $\begin{array}{c}\text { Pump on, }{ }^{(b)} \text { argon gas flow } \\
75 \\
\text { Vacuum, Ar background } \\
15 \\
300 \\
\mathrm{H}_{2}, \mathrm{H}_{2} \mathrm{O}, \mathrm{N}_{2}, \mathrm{O}_{2}, \mathrm{CO}_{2}, \mathrm{Ar}, \mathrm{Kr}, \mathrm{Xe} \\
24\end{array}$ \\
\hline $\begin{array}{l}\text { D. Hot Vacuum Drying (Step 2) } \\
\text { System Configuration } \\
\text { Test Temperature Range, }{ }^{\circ} \mathrm{C} \\
\text { Temperature Ramp Rate, }{ }^{\circ} \mathrm{C} / \mathrm{hr} \\
\text { Atmosphere } \\
\text { Pressure, Torr } \\
\text { Gas Flow Rate, cc/min } \\
\text { Gas Species Monitored } \\
\text { Duration, hr }\end{array}$ & $\begin{array}{c}\text { Pump on, }{ }^{(b)} \text { argon gas flow } \\
75 \text { to } 400 \\
10 \\
\text { Vacuum, Ar background } \\
15 \\
300 \\
\mathrm{H}_{2}, \mathrm{H}_{2} \mathrm{O}, \mathrm{N}_{2}, \mathrm{O}_{2,} \mathrm{CO}_{2}, \mathrm{Ar}, \mathrm{Kr}, \mathrm{Xe} \\
35\end{array}$ \\
\hline
\end{tabular}


Table 3.1. (coritd)

\begin{tabular}{|c|c|}
\hline " $\quad$ Test Segment & Nominal Test Conditions $s^{(a)}$ \\
\hline E. Hot Vacuum Drying (Step 3) & \\
\hline System Configuration & Pump on, ${ }^{(b)}$ argon gas flow \\
\hline Test Temperature, ${ }^{\circ} \mathrm{C}$ & 400 \\
\hline Atmosphere & Vacuum, Ar background \\
\hline Pressure, Torr & 15 \\
\hline Gas Flow Rate, cc/min & 300 \\
\hline $\begin{array}{l}\text { Gas Species Monitored } \\
\text { Duration, hr }\end{array}$ & $\mathrm{H}_{2}, \mathrm{H}_{2} \mathrm{O}, \mathrm{N}_{2}, \mathrm{O}_{2}, \mathrm{CO}_{20}, \mathrm{Ar}, \mathrm{Kr}, \mathrm{Xe}$ \\
\hline F. Cooldown & \\
\hline System Configuration & Pump on, argon gas flow \\
\hline Test Temperature, ${ }^{\circ} \mathrm{C}$ & 400 to 50 \\
\hline Atmosphere & Vacuum \\
\hline Initial Pressure, Torr & 15 \\
\hline Gas Flow Rate, cc/min & 300 \\
\hline Gas Species Monitored & $\mathrm{H}_{2}, \mathrm{H}_{2} \mathrm{O}, \mathrm{N}_{2}, \mathrm{O}_{2}, \mathrm{CO}_{2}, \mathrm{Ar}, \mathrm{Kr}, \mathrm{Xe}$ \\
\hline Duration, $\mathrm{hr}$ & $\sim 100$ \\
\hline G. Pressure Rise Test & \\
\hline System Configuration & Test Chamber Isolated \\
\hline Test Temperature, ${ }^{\circ} \mathrm{C}$ & 50 \\
\hline Atmosphere & Vacuum \\
\hline Initial Pressure, Torr & $<5$ \\
\hline Gas Flow Rate, cc/min & 300 \\
\hline $\begin{array}{l}\text { Gas Species Monitored } \\
\text { Duration hr }\end{array}$ & $\mathrm{H}_{2}, \mathrm{H}_{2} \mathrm{O}, \mathrm{N}_{2}, \mathrm{O}_{2}, \mathrm{CO}_{2}, \mathrm{Ar}, \mathrm{Kr}, \mathrm{Xe}$ \\
\hline $\begin{array}{l}\text { (a) Nominal test design } \\
\text { (b) Vacuum pump was }\end{array}$ & $-x_{1}$ \\
\hline
\end{tabular}

\subsubsection{Cold Vacuum Drying}

While the fuel element was being handled and prepared for the drying test, it was kept damp by sprinkling with deionized water. The amount of surplus liquid water, though small, could not be ascertained. There were no pools of water in the sample boat; however, water was adsorbed into corroded areas, cracks, and crevices. The element was then loaded into the furnace and the test started. An additional $\sim 10 \mathrm{ml}$ of water were added to the sample boat to ensure sufficient free water in the system prior to CVD.

The furnace was first purged with argon to remove as much air as possible. It is possible that a small, but unknown, quantity of water could be lost during this step. The furnace was then isolated and the furnace temperature increased to approximately $50^{\circ} \mathrm{C}$ and allowed to stabilize. The system vacuum pump was then turned on and the system water condenser valved in. Initially, argon was injected for $\sim 80$ minutes at a rate of $324 \mathrm{cc} / \mathrm{min}$. When the water partial pressure, as indicated by the moisture monitor, began to drop, the flow was turned off. After the system pressure dropped to a reasonable level, the vacuum pump was valved out and only the condenser left in the system. When the system pressure became lower than the condenser could extract, the condenser was valved out of the gas loop and the 
vacuum pump valved back in. This process was repeated until the vacuum pump could safely evacuate the remaining water. No argon was injected during this part of the CVD test. The remainder of CVD was conducted at an ultimate pressure of $\sim 0.2$ Torr for $\sim 16 \mathrm{hr}$. The purpose of the CVD portion of the test was to determine if CVD is successful in removing the majority of the free water from the system in a reasonable length of time.

\subsubsection{Pressure Rise Test}

The Pressure Rise Test involved isolating the system and measuring any pressure increase while at CVD pressure and temperature conditions. The purpose of the Pressure Rise Test was to determine the effectiveness of the preceding CVD process. This test was conducted by valving the vacuum pump out of the gas loop and closing the exhaust valves. The condition for acceptance of this portion of the test is a total system pressure rise of less than 0.5 Torr in a 1-hr time period. If this condition is not met, the system is re-opened to the vacuum pump and the Pressure Rise Test repeated.

\subsubsection{Hot Vacuum Drying, Step 1}

Following completion of the Pressure Rise Test, the vacuum pump was re-opened to the system retort; argon gas flow was established at a rate of $\sim 324 \mathrm{cc} / \mathrm{min}$; and the retort temperature was increased to $\sim 76^{\circ} \mathrm{C}$. This condition was held for a period of $\sim 25 \mathrm{hr}$. This portion of the test can be used to obtain isothermal hydrogen and water release data for assessing oxidation of the fuel at low temperatures.

\subsubsection{Hot Vacuum Drying, Step 2}

The second step of the HVD process involved raising the temperature of the retort from $\sim 80^{\circ} \mathrm{C}$ to $\sim 400^{\circ} \mathrm{C}$ at a carefully controlled rate while maintaining the same argon flow and pressure conditions. Thus, any release of gas species during this temperature rise could be assigned to a specific temperature. The second step of the HVD process was conducted for about $33 \mathrm{hr}$.

During this step, hydrogen may be released from the fuel through the decomposition of uranium hydride (Cotton 1988); this reaction is rapid at temperatures greater than $250^{\circ} \mathrm{C}$.

$$
\mathrm{UH}_{3} \rightarrow \mathrm{U}+\frac{3}{2} \mathrm{H}_{2}
$$

Water may also be liberated by various hydrated species found on fuel elements, such as hydrates of uranium oxides, aluminum hydroxides, and hydrated iron oxides. Water is also released slowly along a "tortuous path" from beneath corroded parts of the fuel element and from behind the cladding. The released water can react with the fuel element to generate hydrogen through the reactions:

$$
\begin{gathered}
\mathrm{U}+2 \mathrm{H}_{2} \mathrm{O} \rightarrow \mathrm{UO}_{2}+2 \mathrm{H}_{2} \\
\mathrm{UH}_{3}+2 \mathrm{H}_{2} \mathrm{O} \rightarrow \mathrm{UO}_{2}+\frac{7}{2} \mathrm{H}_{2}
\end{gathered}
$$




\subsubsection{Hot Vacuum Drying, Step 3}

The final step of the HVD process involved holding the temperature of the retort at $\sim 400^{\circ} \mathrm{C}$ while again maintaining the same argon flow and pressure conditions as in steps 1 and 2. This step will yield isothermal release data for any remaining hydrated species on the fuel element and for oxidation of uranium by any remaining water. This final step of the HVD process was conducted for about $10 \mathrm{hr}$.

\subsubsection{System Cooldown and Post-Test Pressure Rise Test}

Following completion of the final HVD step, the system retort was allowed to cool to $\sim 50^{\circ} \mathrm{C}$ while maintaining the same vacuum and flow conditions, and then another Pressure Rise Test was conducted to determine the baseline in-leakage rate of air into the retort from the cell environment. Knowing this rate is important to allow for correction of the system and moisture pressure increase rates determined in the initial post-CVD Pressure Rise Test. Since the conditions for the post-HVD test are identical to those used for the initial test, the assumption is made that the air in-leakage rate also should be nearly the same.

\subsection{Calculation of Water and Hydrogen Inventories}

Assuming ideal gas behavior of the water vapor, total water inventory $(\mathrm{m})$ in the system during those portions of the test conducted with argon flowing into the retort can be approximated from the measured water vapor pressure and the argon gas flow as follows:

$$
\frac{d \mathrm{~m}}{d t}=\frac{\mathrm{M}}{\mathrm{V}_{0}} \cdot \frac{\mathrm{P}_{\mathrm{w}}}{\left(\mathrm{P}_{\mathrm{t}}-\mathrm{P}_{\mathrm{w}}\right)} \cdot \frac{d \mathrm{~V}}{d t}
$$

where $d \mathrm{~m} / d t$ is the rate of water removal in grams per minute, $\mathrm{M}$ is the molecular mass of water in grams per mole, $d \mathrm{~V} / d t$ is the flow rate in liters per minute (at the calibration temperature of $25^{\circ} \mathrm{C}$ ), $\mathrm{V}_{0}$ is the molar volume of gas at $25^{\circ} \mathrm{C}$ and 1 atmosphere in liters per mole, $P_{w}$ is the partial pressure of water vapor in Torr, and $P_{t}$ is the total pressure in Torr. The total amount of water released is given by integrating the rate data over time.

The hydrogen inventory may be calculated in a similar fashion with the $\left[\mathrm{P}_{\mathrm{w}} /\left(\mathrm{P}_{\mathrm{t}}-\mathrm{P}_{\mathrm{w}}\right)\right]$ expression in the above equation replaced with the measured atom fraction of hydrogen. For the purposes of this report, all hydrogen data are plotted in Torrl rather than grams. At the calibration conditions of the argon flow controller, 1 Torrll is equivalent to approximately $0.11 \mathrm{mg}$ of hydrogen.

The assumptions made in estimating the water and hydrogen values are

- The flow into the retort is approximately equal to the flow out (i.e., contributions to the flow from other gas species such as hydrogen are neglected).

- The argon mass flow is referenced to $25^{\circ} \mathrm{C}$ (as determined from the calibration of the flow gauges).

- The sample gas is at the same temperature as the calibration gas (GC and MS measurements). 


\subsection{Visual Examinations of Element 6603M}

An N-Reactor fuel assembly consists of an inner element and outer element made from a uranium alloy co-extruded with a Zircaloy-2 cladding. Both elements are annular, right-cylinders. The inner element has a smaller outer diameter and is held in place within the outer element.

Fuel element $6603 \mathrm{M}$, chosen for Run 5, was an outer element removed from the K-West Basin in 1996. The element had been in sealed water storage in the K-West Basin since 1983. This fuel element was selected to represent a classification of fuel damage termed "broken bottom end" (Lawrence 1997). The furnace drying test series (of which this is Run 5 of 8) were intended to progress from intact (unbreached) fuel elements to severely damaged fuel elements. This fuel element, therefore, was to represent a fuel element which falls between fuel elements which appear to be only broken (as in Run 3) and those which are severely damaged (as will be tested in Runs 6, 7, 8).

The fuel element had been kept in K-Basin water at the PTL storage basin since it was loaded into its SFEC and shipped to the facility in 1996. The first relatively detailed examination of the fuel element was conducted just before the drying test and is discussed below.

\subsection{Pre-Test Visual Examination}

The fuel element was removed from its SFEC and examined using a CCD color video camera in the PTL F-cell. The fuel element was split open at one end with some of the uranium fuel material missing due to corrosion. The other end of the fuel element appeared to be intact. The visual inspection of the remainder of the fuel element suggested the element had no additional breaches.

Figure 4.1 shows two views of the damaged end of the fuel element. Portions of the end cap are broken away and missing from the element. The outer cladding is split and visibly forced out as a result
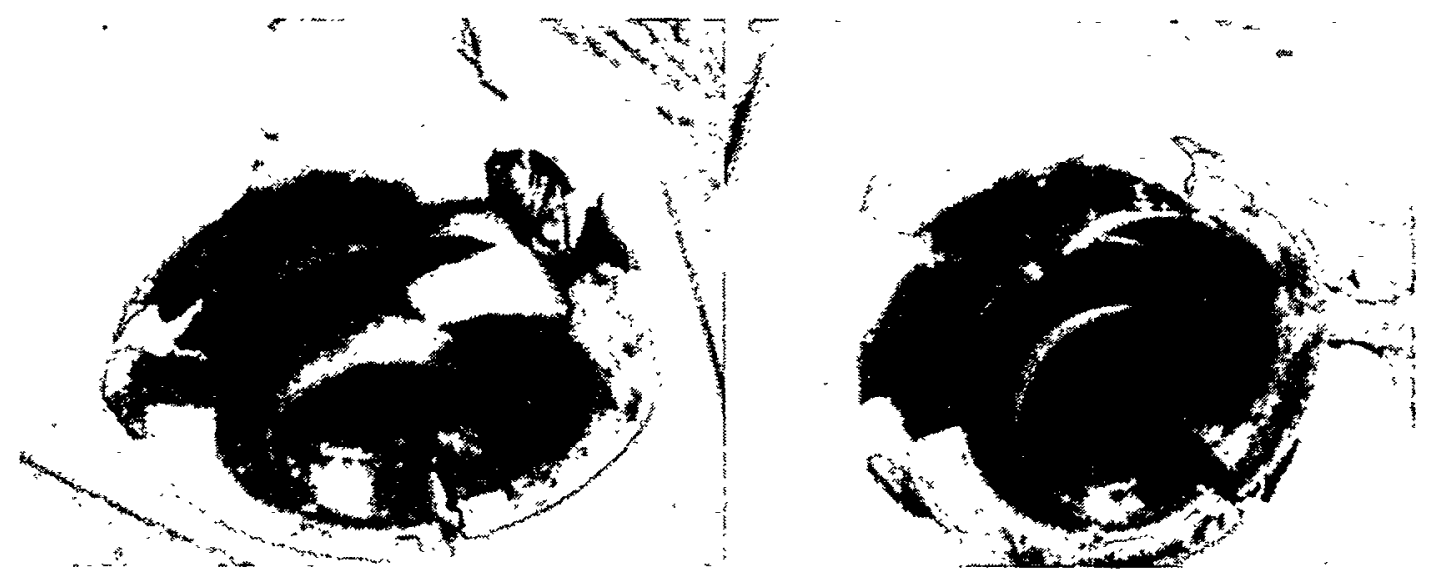

Figure 4.1. Two Pre-test Views of the Damaged End of Fuel Element 6603M. The exposed cracked uranium fuel matrix can be seen clearly in each view. 
of the fuel corrosion, and the inner cladding is also split. Cracks can be seen in the exposed uranium fuel material as is typical for this type of fuel failure.

The fuel element appeared to have a light coating on the surface. Attempts to collect the coating were unsuccessful because the material was thin. A large area would have had to be brushed to collect a sufficient sample for analysis by XRD or SEM. That would have changed the overall surface condition of the fuel element which was not desired.

No other significant features (no apparent cracks and limited surface coatings) were evident in the pre-test visual examination. Additional pre-test views of Element $6603 \mathrm{M}$ are presented for comparative purposes with post-test results in the next section.

\subsection{Post-Test Visual Examination}

The changes or lack of changes observed between the pre- and post-test analyses are significant. One of the obvious changes to the fuel element during this drying test was the change of overall color of the fuel element. The thin coating material darkened as a result of the heat treatment. This could be due to the transformation of uranium oxy-hydrates releasing water and leaving behind simpler oxide phases. Some oxides are known to be dark colored as observed on the fuel element. Figure 4.2 shows a pre- and post-test view of the intact end of Element $6603 \mathrm{M}$. This end appears to have been placed in the down position at one time during storage as it appears similar to other ends stored in sludge (distinct band running circumferentially around the element, different coating appearance). The post-test view of the same area shows the color difference of the coating, but no other significant changes. The circumferential band is still visible and some of the other distinct markings that were present in the pre-test view are also still present in the post-test views.

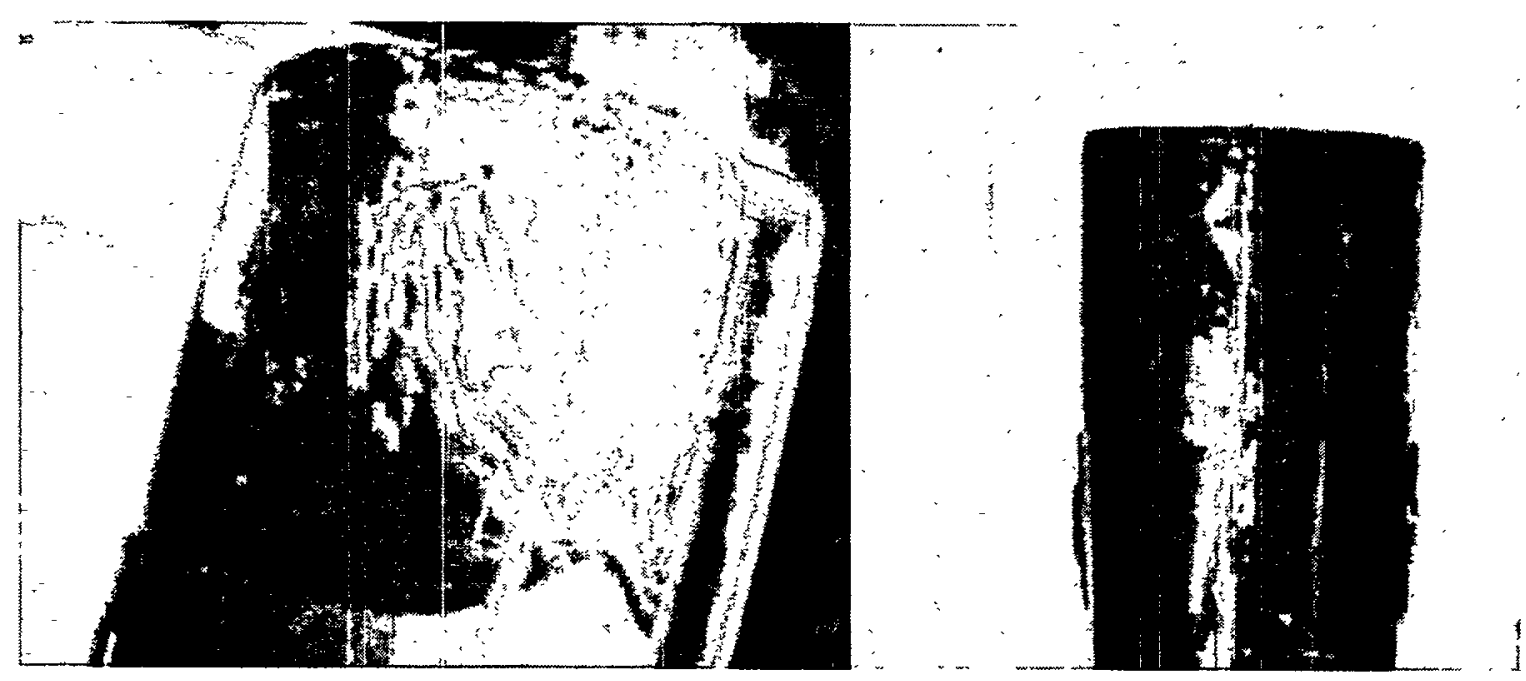

Figure 4.2. Pre-test (left) and Post-test (right) Views of the Intact End of Element 6603M. The views are of the same region. The circumferential band around the fuel element is visible in both views as are the distinctive white markings (which are darker in the post-test view). 
Figure 4.3 shows a pre- and post-test view of the damaged end. The damaged end of the fuel element did not appear to undergo any significant visual appearance changes besides the color change. The fuel cladding may have opened up slightly due to fuel oxidation, as small fuel pieces (likely oxidized) fell out of the fuel element as it was rotated for visual examination. These small shard-like particles are visible in the post-test view of the fuel element in Figure 4.3.

While no significant changes were at first observed in the post-test view, the hydrogen release data from this test (Section 5.4) showed a release peak at $330^{\circ} \mathrm{C}$ that was not observed in previous tests. That release was also accompanied by a release of fission gases which suggested that a fresh surface of uranium metal was exposed during the test. The video tapes were reexamined more closely to determine if there were any differences between the pre- and post-test views. Evidence of a new breach in the fuel cladding was found along the side of the fuel element. Still images captured from the video of one area along the side of the fuel element are shown in Figure 4.4. These images were captured from portions of the tape during times when the camera was being moved. The resolution of the still images is reduced due to this movement. However, after careful study, it was concluded that a new breach occurred during drying. This breach could have provided the fresh uranium metal surface which would have reacted with residual water and oxygen in the test system. This reaction would account for the hydrogen release peak and the release of fission gases. No other significant changes were noted in the post-test appearance of the fuel element.
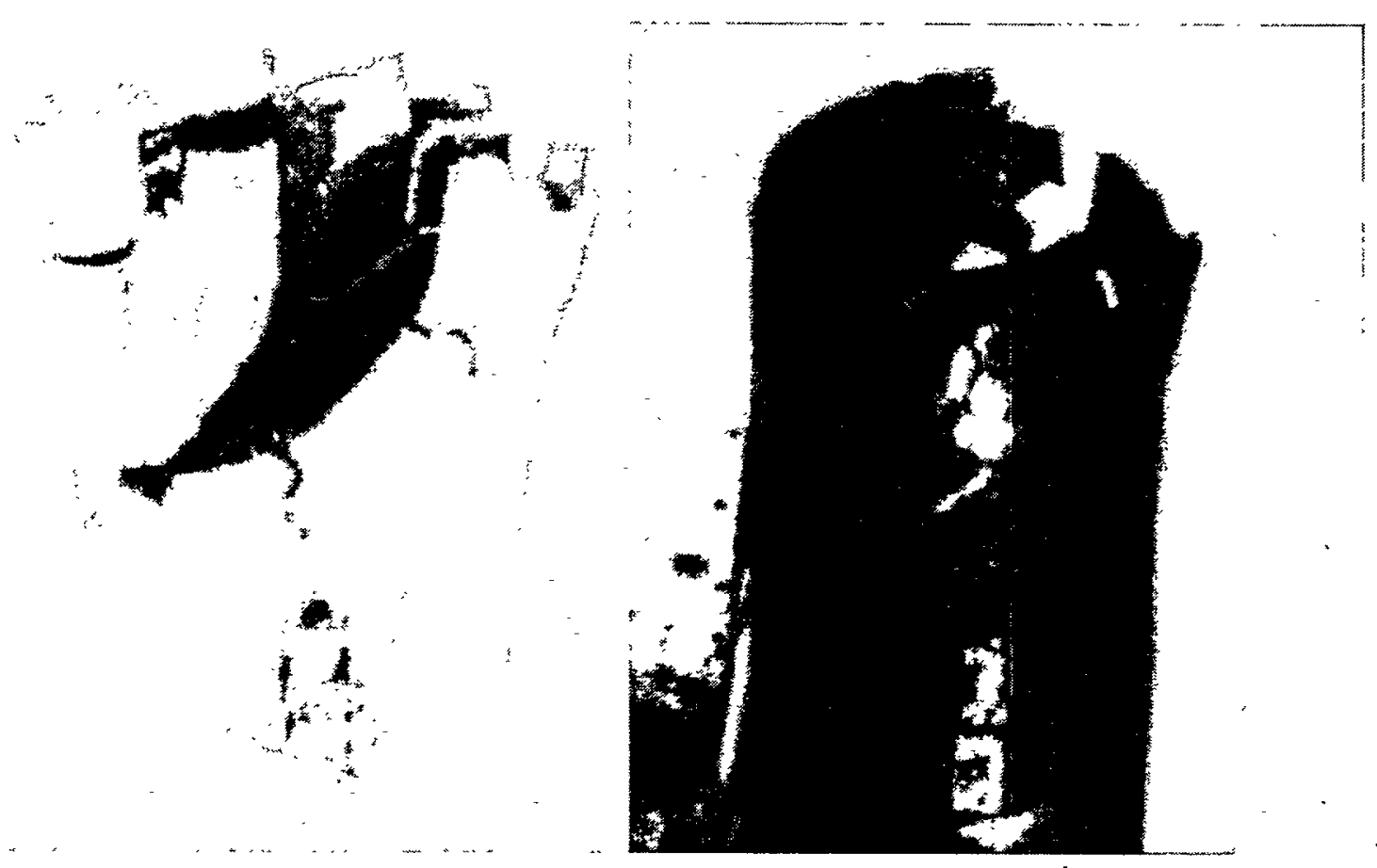

Figure 4.3. Pre-test (left) and Post-test (right) Views of the Damaged End. Small shards of fuel material can be seen in the background of the image. These particles fell freely from the fuel element as it was rotated for viewing. 


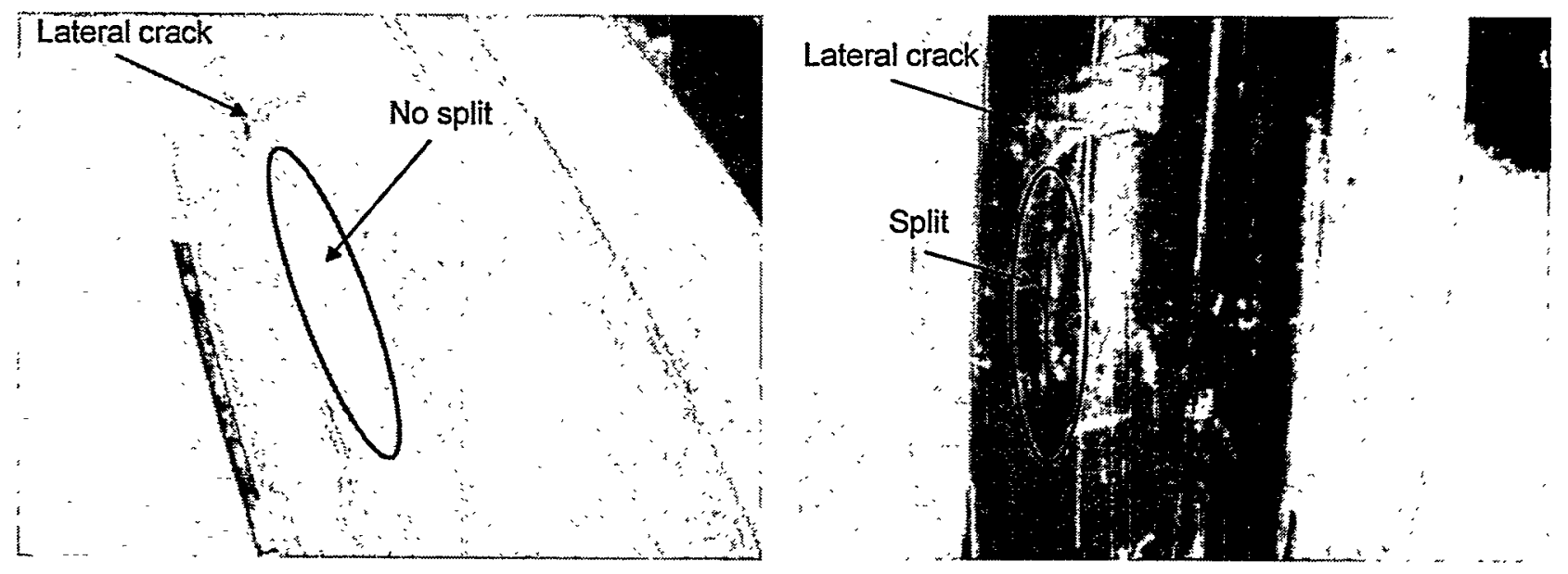

Figure 4.4. Pre- and Post-test View of a Portion of the Side of Element 6603M. A new breach was detected which likely formed during the drying of the fuel element. 


\subsection{Experimental Results}

In the following sections, the experimental data collected during the drying test are expanded and plotted for each segment. Summary results from the test are plotted in Figure 5.1. This figure shows the system moisture level response to the pressure changes and the retort tube temperatures during the test. Time intervals for the various test segments are shown in the upper section of the plot, and are also outlined in Table 5.1. The temperatures shown in Figure 5.1 were recorded from one of seven thermocouples (TE-07) on the system located near the center of the retort. The pressure data were taken from the 0 to 1000 Torr Baratron sensor (PE-06) located upstream of the retort.

\subsection{Cold Vacuum Drying}

The water release from the CVD portion of the test is shown in Figure 5.2. This plot spans the period when the furnace was loaded with the fuel element through to the Pressure Rise Test. The baseline moisture partial pressure in the system prior to heating was $\sim 14$ Torr at a retort temperature of $\sim 24^{\circ} \mathrm{C}$. Total system pressure was $\sim 751$ Torr, with no argon gas flow. After heating to $\sim 51^{\circ} \mathrm{C}$, the moisture pressure and system pressure stabilized at $\sim 12$ Torr and $\sim 847$ Torr, respectively. Assuming ideal gas behavior, the pressure after heating is approximately 28 Torr higher than expected. This excess pressure has been observed in all the previous tests, except for the first dry run, and may have been due to gases evolved during the heatup, such as hydrogen from moisture reactions, and gases dissolved in the free water. Another explanation for the calculated pressure difference is that the average retort temperature was somewhat greater than $51^{\circ} \mathrm{C}$.

The CVD phase started at an elapsed time (ET) of 270 minutes when the vacuum pump was opened briefly in order to "rough-out" the system retort to 70 Torr (total pressure). At this point, the vacuum pump was valved out of the system, allowing pumping by only the condenser. Figure 5.2 shows that the moisture pressure indication rose almost immediately to $\sim 14$ Torr, and "saturated" at this pressure for about $50 \mathrm{~min}$. The saturation behavior was the result of the dew point exceeding the maximum of $20^{\circ} \mathrm{C}$ for the Panametrics moisture probe. At an ET of 343 minutes, the condenser was valved out and the vacuum pump valved back in. By the end of $C V D(E T=1234 \mathrm{~min})$, the moisture pressure had dropped to $\sim 0.3$ Torr, whereas the total pressure was indicating a slightly lower value at $\sim 0.2$ Torr. The reason for this apparent discrepancy is not clear, but may indicate the inherent combined accuracies of the Baratron and Panametrics sensors. Approximately $4 \mathrm{ml}$ of water were collected in the condenser during CVD: The reason for the incomplete recovery of water is not clear, but may be due to hold-up in unheated system components such as filters. It is also possible that some evaporation occurred after adding the initial water to the fuel. The run log indicated the furnace had to be opened after loading the fuel element prior to the start of the test in order to properly insert the axial thermocouple. 


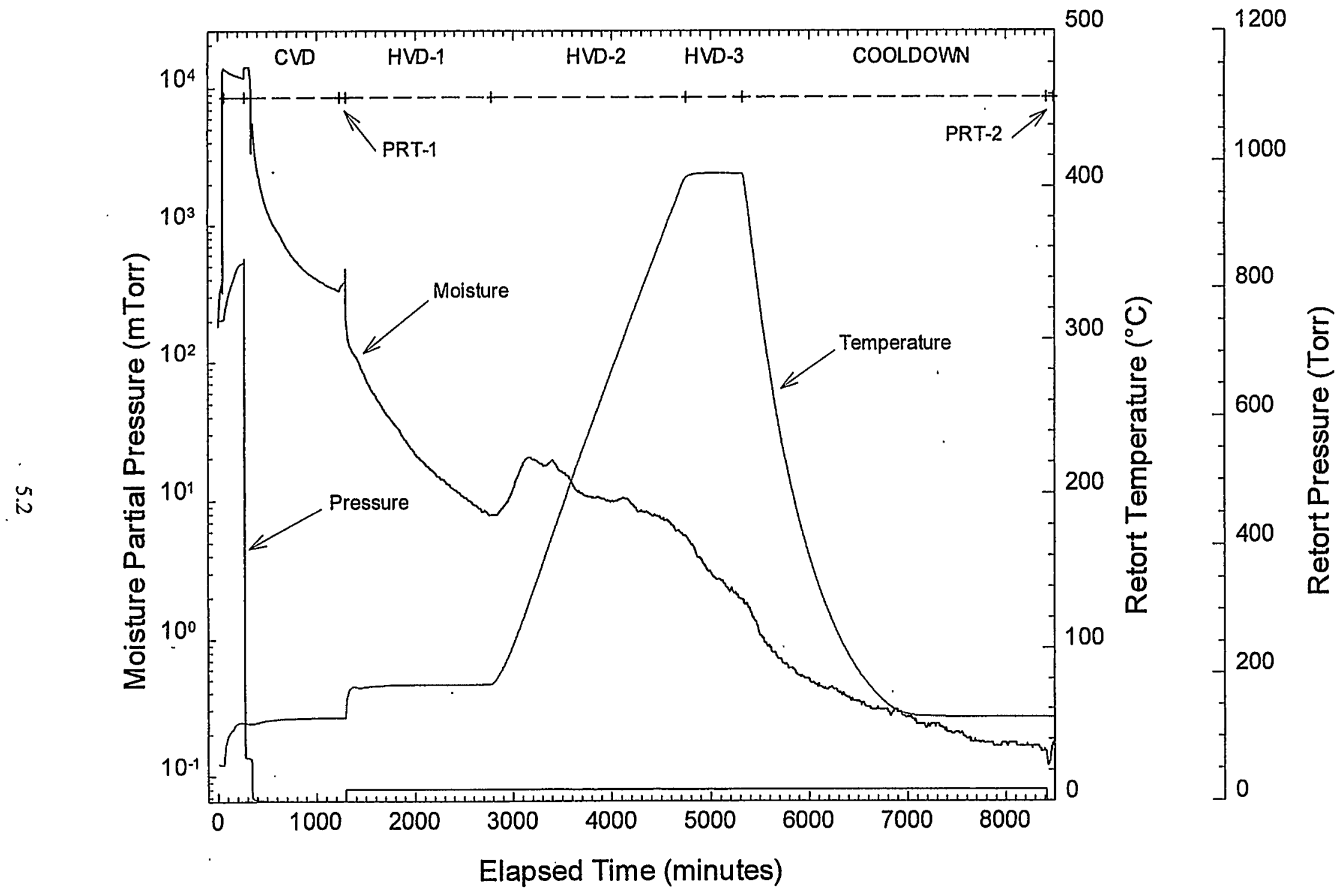

Figure 5.1. Drying of SNF Element 6603M, Summary Plot 
Table 5.1. Fuel Element 6603M Drying Run Time Line

\begin{tabular}{|c|c|c|}
\hline Activity & Date/Time & $\begin{array}{l}\text { Elapsed Time } \\
\text { (min) }\end{array}$ \\
\hline $\begin{array}{l}\text { Start of Test } \\
\text { Heat furnace to } \sim 50^{\circ} \mathrm{C}\end{array}$ & 01/06/98 13:09 & 64 \\
\hline $\begin{array}{l}\text { Cold Vacuum Drying Test } \\
\text { Open pump valve } \mathrm{e}^{(\mathrm{a})} \text { and condenser to furnace (initial) } \\
\text { Open pump valve, close condenser valve (final) }\end{array}$ & $\begin{array}{l}01 / 06 / 9816: 35 \\
01 / 06 / 9817: 48\end{array}$ & $\begin{array}{l}270 \\
343\end{array}$ \\
\hline $\begin{array}{l}\text { Pressure Rise Test } \\
\text { Close pump (isolate furnace) } \\
\text { Open pump valve }\end{array}$ & $\begin{array}{l}01 / 07 / 9808: 39 \\
01 / 07 / 9809: 39\end{array}$ & $\begin{array}{l}1234 \\
1295\end{array}$ \\
\hline $\begin{array}{l}\text { Hot Vacuum Drying Test (Step 1) } \\
\text { Start argon flow }(\sim 320 \mathrm{cc} / \mathrm{min}) \text {, raise furnace temperature to } \\
\sim 80^{\circ} \mathrm{C} \text { and hold }\end{array}$ & 01/07/98 09:40 & 1296 \\
\hline $\begin{array}{l}\text { Hot Vacuum Drying Test (Step 2) } \\
\text { Raise furnace temperature to } \sim 400^{\circ} \mathrm{C} @ 10^{\circ} \mathrm{C} / \mathrm{min}\end{array}$ & $01 / 08 / 98 \quad 10: 26$ & 2781 \\
\hline $\begin{array}{l}\text { Hot Vacuum Drying Test (Step 3) } \\
\text { Hold furnace temperature at } \sim 400^{\circ} \mathrm{C} \\
\end{array}$ & 01/09/98 19:17 & 4752 \\
\hline $\begin{array}{l}\text { System Cooldown } \\
\text { Reduce temperature of retort to } \sim 50^{\circ} \mathrm{C} \text {, maintain argon flow }\end{array}$ & 01/10/98 04:50 & 5325 \\
\hline $\begin{array}{l}\text { Post-Test Pressure Rise Test } \\
\text { Turn off argon flow, and close pump valve (isolate furnace) } \\
\text { Turn off furnace heaters, end test }\end{array}$ & $\begin{array}{l}01 / 10 / 9808: 23 \\
01 / 12 / 9809: 35\end{array}$ & $\begin{array}{l}8418 \\
8490\end{array}$ \\
\hline
\end{tabular}

\subsection{Pressure Rise Tests}

The results of the two pressure rise phases of the drying test (post-CVD and post-HVD) are shown in Figures 5.3 and 5.4. As discussed earlier, the purpose of the post-HVD test was to determine as best as possible the ambient air in-leakage rate into the system as it had been configured for the drying test. While under vacuum conditions, with no argon flow, any air in-leakage will contribute to the data signals observed for the various process gases measured during the test, particularly water and hydrogen (from oxidation). The data plotted for the total pressure are from the 0 to 1000 Torr Baratron sensor (PE-06) located upstream of the retort. This sensor has higher sensitivity and lower noise than the 0 to 10,000 Torr Baratron located downstream of the retort. To calculate the total water mass removed from the retort, however, pressure data from the 0 to 10,000 Torr sensor (PE-01) were used as the moisture sensor was also located on the downstream side of the retort. During argon flow conditions, the pressure drop across the retort was $\sim 4$ Torr.

The post-CVD Pressure Rise Test was conducted over an ET of $1234 \mathrm{~min}$ to $1295 \mathrm{~min}$. Both the total pressure and the moisture pressure showed nearly linear pressure rises over the course of the test.

Regression fits (dotted lines in the figure) yielded a total pressure rise rate of $\sim 0.2 \mathrm{Torr} / \mathrm{hr}$ (well below the $0.5 \mathrm{Torr} / \mathrm{hr}$ criterion for the test), and a moisture pressure rise rate of $\sim 0.04 \mathrm{Torr} / \mathrm{hr}$. 

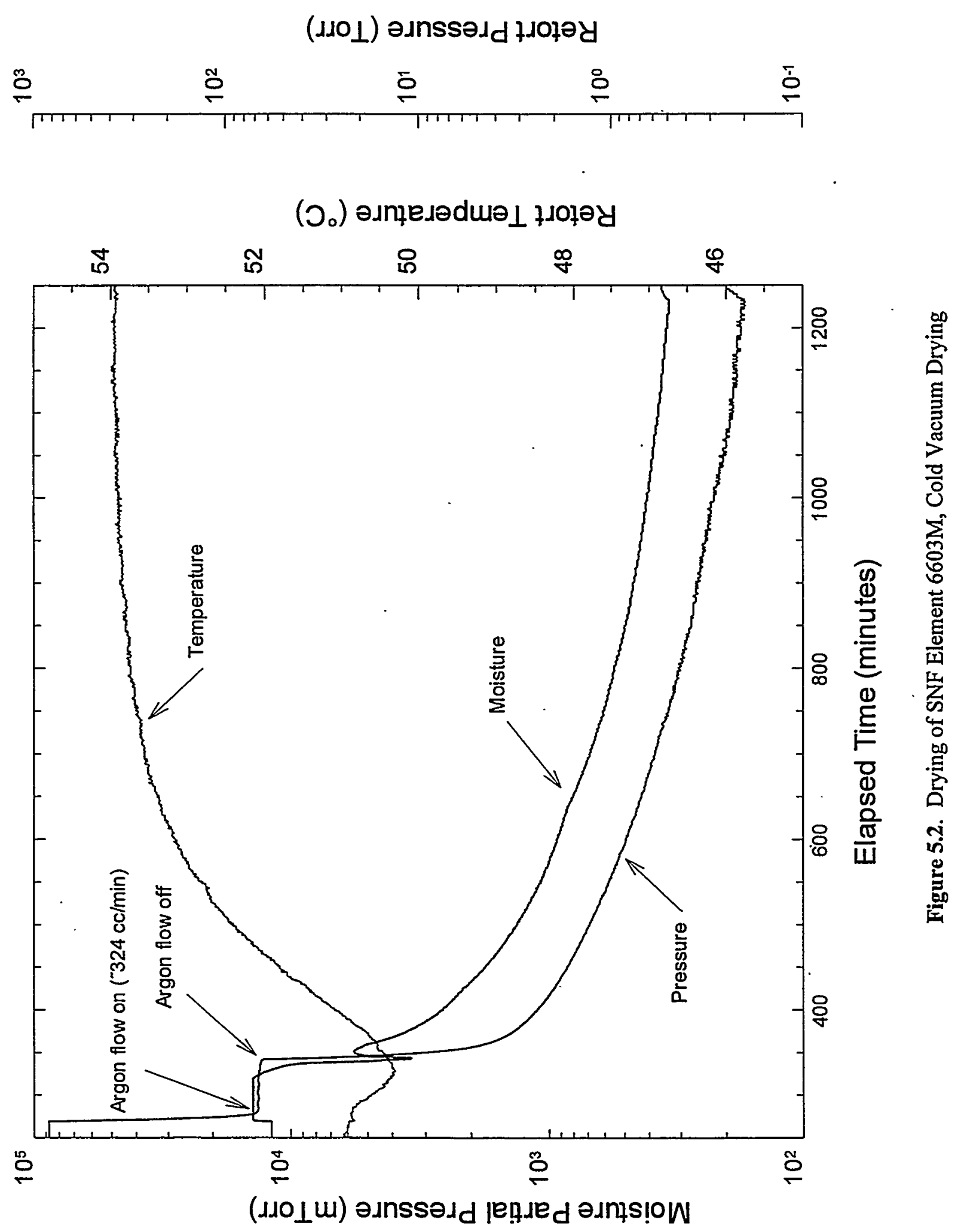

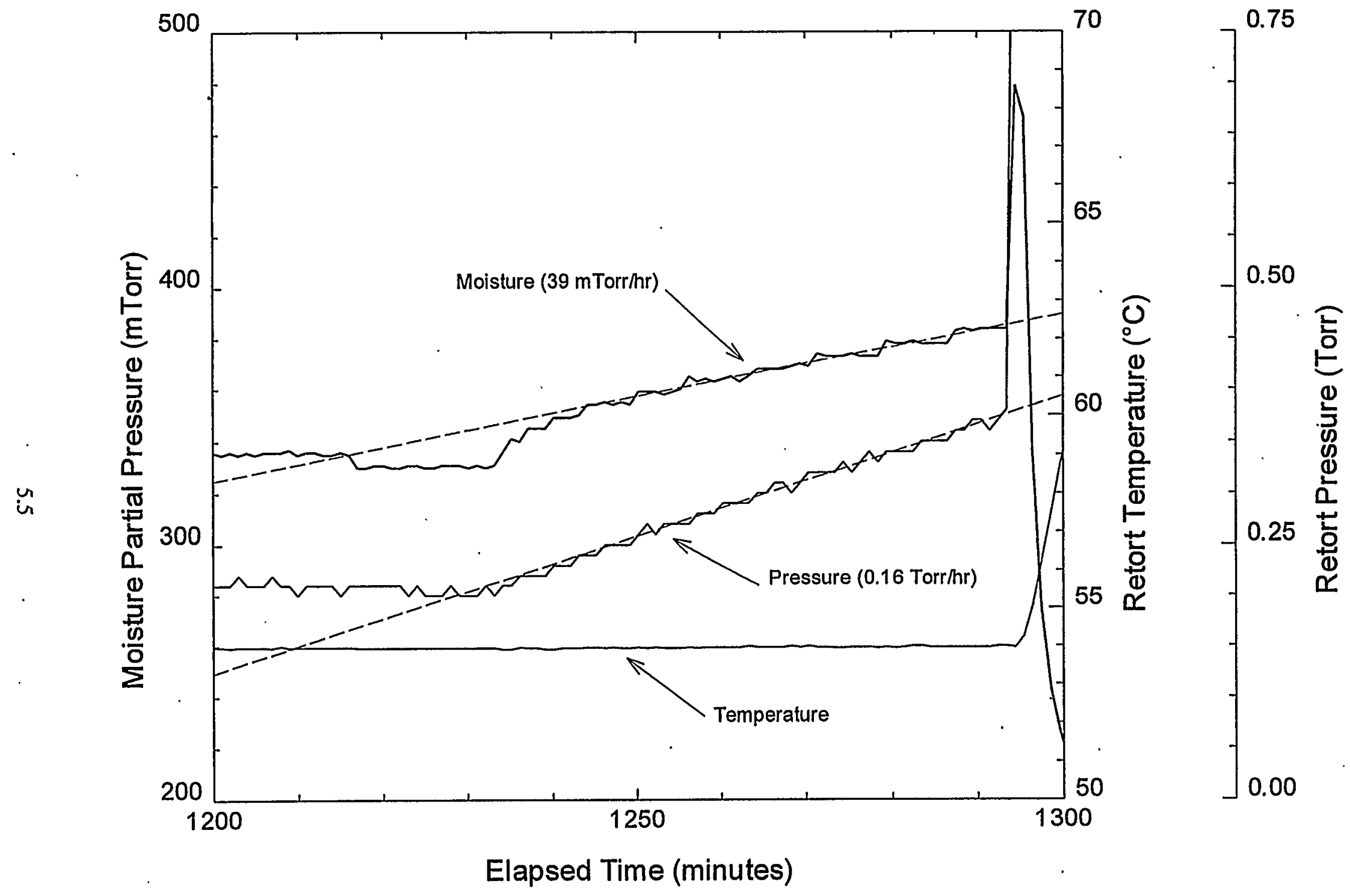

Figure 5.3. Drying of SNF Element 6603M, Post-CVD Pressure Rise Test 
Assuming that the water vapor pressure increase is from water sources within the test system, and assuming ideal gas behavior of the water vapor, the rate of desorption of the water $(d n / d t)$ will be given by:

$$
\frac{d \mathrm{n}}{d t}=\frac{\mathrm{V}}{\mathrm{RT}} \cdot \frac{d \mathrm{P}}{d t}
$$

where $\mathrm{n}$ is the number of moles of gas, $\mathrm{V}$ is the volume of the system $\left(\sim 10,000 \mathrm{~cm}^{3}\right), \mathrm{R}$ is the gas constant $\left(82.06 \mathrm{~cm}^{3} \cdot \mathrm{atm} / \mathrm{g}-\mathrm{mol} \cdot \mathrm{K}\right), \mathrm{T}$ is the temperature $(-326 \mathrm{~K})$, and $d \mathrm{P} / d t$ is the rate of change in the pressure given by the slope of the regression line. The total amount of water released to the system during the Pressure Rise Test is given by the integral of the above equation. Assuming a total period of $62 \mathrm{~min}$, the total amount of water released was $\sim 0.4 \mathrm{mg}$. Assuming a total surface area of $\sim 8900 \mathrm{~cm}^{2}$ for the system (total surface area of the retort, sample boat, tubing, and an outer fuel element), and $10^{15}$ atoms per $\mathrm{cm}^{2}$ as the monolayer gas density on surfaces, approximately two monolayer equivalents of $\mathrm{H}_{2} \mathrm{O}$ were evaporated.

The results of the post-HVD pressure rise measurements are shown in Figure 5.4. Again, both the total pressure and the moisture pressure showed essentially linear increases with time, however with significantly lower slopes than observed for the earlier post-CVD test. The total pressure rise has a regression slope of $\sim 0.04 \mathrm{Torr} / \mathrm{hr}$, and the moisture pressure rise has a slope of $\sim 0.07 \mathrm{mTorr} / \mathrm{hr}$. The rate of increase in the total pressure is about a factor of three lower than observed in Runs 3 and 4, suggesting improved system sealing.

The ratio of the water pressure rise to the total pressure rise is $\sim 0.002$, which is somewhat lower than would be expected just from humidity alone in air in-leakage from the cell environment (air at $20^{\circ} \mathrm{C}$ and $25 \%$ relative humidity would yield a water pressure-to-total pressure ratio of $\sim 0.007$ ). A likely explanation for the low moisture pressure rise in the post-HVD test is that the previous vacuum drying of the fuel element at temperature (during CVD and HVD) resulted in the formation of hygroscopic species which "gettered" most of the moisture from either air in-leakage or moisture remaining on the element that would otherwise have been released. A similar, but more noticeable effect was observed in Run 4 .

Comparison of the pressure data from the two pressure rise tests indicates that the total pressure rise observed in the initial post-CVD test is only partially caused by residual moisture and/or air in-leakage. The difference between the total pressure rise and the moisture pressure rise for the post-CVD test $(\sim 0.12 \mathrm{Torr} / \mathrm{hr})$ is higher than can be explained by air in-leakage into the retort alone as measured in the post-HVD test. This suggests that other sources of gas are responsible for some of the observed total pressure rise in the post-CVD test. A slight increase in the signals for hydrogen and for xenon isotopes were noted in the MS data during CVD.

\subsection{Hot Vacuum Drying}

The first segment of HVD, shown in Figure 5.5, includes the ramp and hold from $\sim 50^{\circ} \mathrm{C}$ to $\sim 80^{\circ} \mathrm{C}$ in flowing argon gas $(325 \mathrm{cc} / \mathrm{min})$ under partial vacuum. HVD-1 occurred over an ET of $1296 \mathrm{~min}$ to 

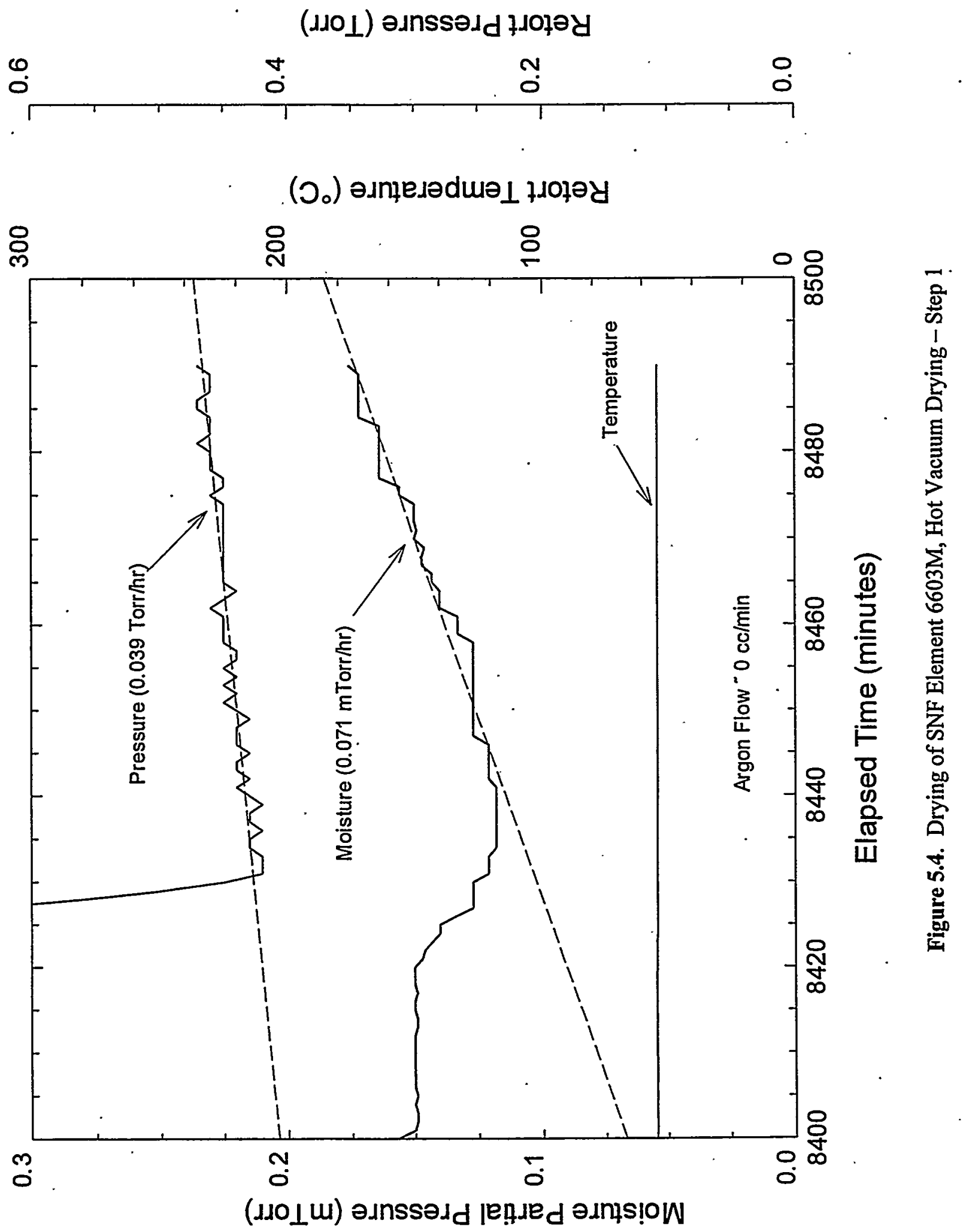
$2781 \mathrm{~min}$. The moisture pressure decreased steadily from $\sim 400 \mathrm{~m}$ Torr to $\sim 7 \mathrm{mTorr}$ during the $\sim 80^{\circ} \mathrm{C}$ phase. Total system pressure was essentially constant over this first HVD phase at $\sim 19$ Torr. Total water removed was $\sim 0.9 \mathrm{~g}$.

The second HVD phase involved maintaining the same system conditions as in HVD-1, but raising the temperature slowly from $\sim 80^{\circ} \mathrm{C}$ to $\sim 400^{\circ} \mathrm{C}$ at a rate of $10^{\circ} \mathrm{C} / \mathrm{hr}$. HVD-2 occurred over an ET of $2781 \mathrm{~min}$ to $4752 \mathrm{~min}$, and is shown in Figure 5.6. During the temperature rise, the moisture pressure increased, showing three diffuse peaks at $\sim 130^{\circ} \mathrm{C}(-20 \mathrm{mTorr}), \sim 173^{\circ} \mathrm{C}(\sim 19 \mathrm{mTorr})$, and $\sim 300^{\circ} \mathrm{C}$ $(\sim 10 \mathrm{mTorr})$. Total system pressure remained essentially constant at $\sim 19$ Torr. These peaks are an indication of water release from chemisorbed sites (i.e., hydrated species) at higher temperatures. Total water removed during the second phase of HVD was $\sim 0.4 \mathrm{~g}$, approximately one half of that removed during the first phase.

The third and final phase of HVD is shown in the left-hand side of Figure 5.7 (ET of $4752 \mathrm{~min}$ to $5325 \mathrm{~min}$ ), and covered the temperature hold period at $\sim 400^{\circ} \mathrm{C}$. This period is characterized by a steady decrease in the moisture pressure from $\sim 1.3 \mathrm{~m}$ Torr to $\sim 0.3 \mathrm{mTorr}$. Total water removed was $\sim 30 \mathrm{mg}$.

Following the final HVD phase, the system was allowed to cool to $\sim 50^{\circ} \mathrm{C}$ in preparation for the posttest pressure rise test discussed above. Water removed during the system cooldown was $\sim 21 \mathrm{mg}$. Total system pressure remained constant at $\sim 18.5$ Torr during HVD-3 and cooldown.

\subsection{Gas Chromatograph Measurements}

The GC was used to measure hydrogen in the sample gas during the HVD portion of the drying test, when argon was flowing through the system. It was not possible to sample for hydrogen using the gas chromatograph during the CVD portion of the test since that portion of the test was conducted with no flow of argon gas. As discussed earlier, the hydrogen concentration data have been converted from ppmv to Torr-1 so that the absolute quantity of hydrogen gas released can be determined independent of argon flow rate. To determine the location of the hydrogen peaks during HVD, and the integrated amounts of hydrogen involved with each peak, the HVD hydrogen data were deconvoluted using a commercial peak fitting program, PeakFit ${ }^{\mathrm{TM}}$. A five-parameter asymmetrical fitting function (Pearson IV) was used to fit each of the separate deconvoluted peaks.

Measured hydrogen release during the HVD segments of the drying test is shown in Figure 5.8. There are five main peaks, four of which occurred during the HVD-2 temperature ramp, and the remaining peak occurred during HVD- 1 at $\sim 80^{\circ} \mathrm{C}$. Deconvolution of the data places the HVD-2 peaks at temperatures of $\sim 127^{\circ} \mathrm{C}, \sim 160^{\circ} \mathrm{C}, \sim 253^{\circ} \mathrm{C}$, and $\sim 332^{\circ} \mathrm{C}$. Approximately 770 Torr $\cdot 1$ ( $\sim 83 \mathrm{mg}$ ) of hydrogen was released during the entire HVD process, over a time period of $\sim 68 \mathrm{hr}$, with the majority being released during HVD-2.

As described in Section 3.2.5, HVD-1 is nearly isothermal, and can therefore be used to provide information on reaction kinetics. During HVD-1, the hydrogen signal first increases, and then later decreases steadily with time. By contrast, the.water signal decreases steadily with time during HVD-1. 


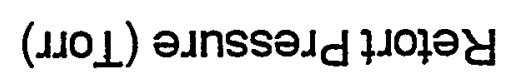

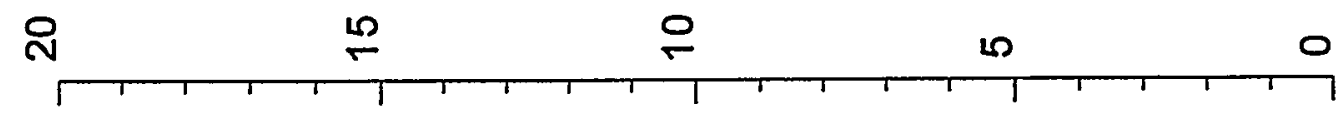

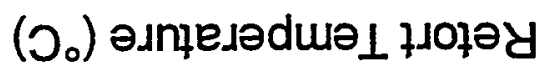

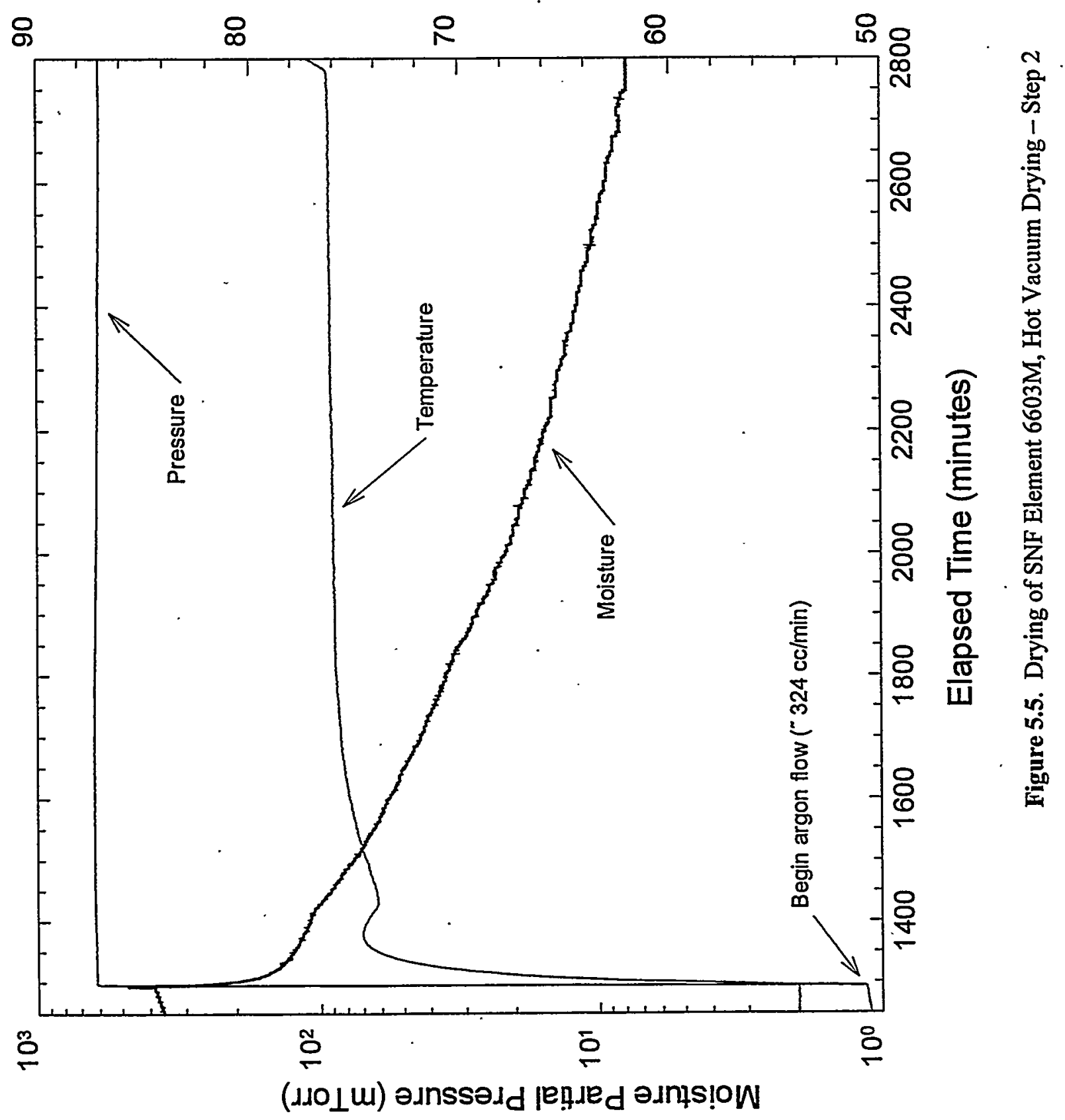



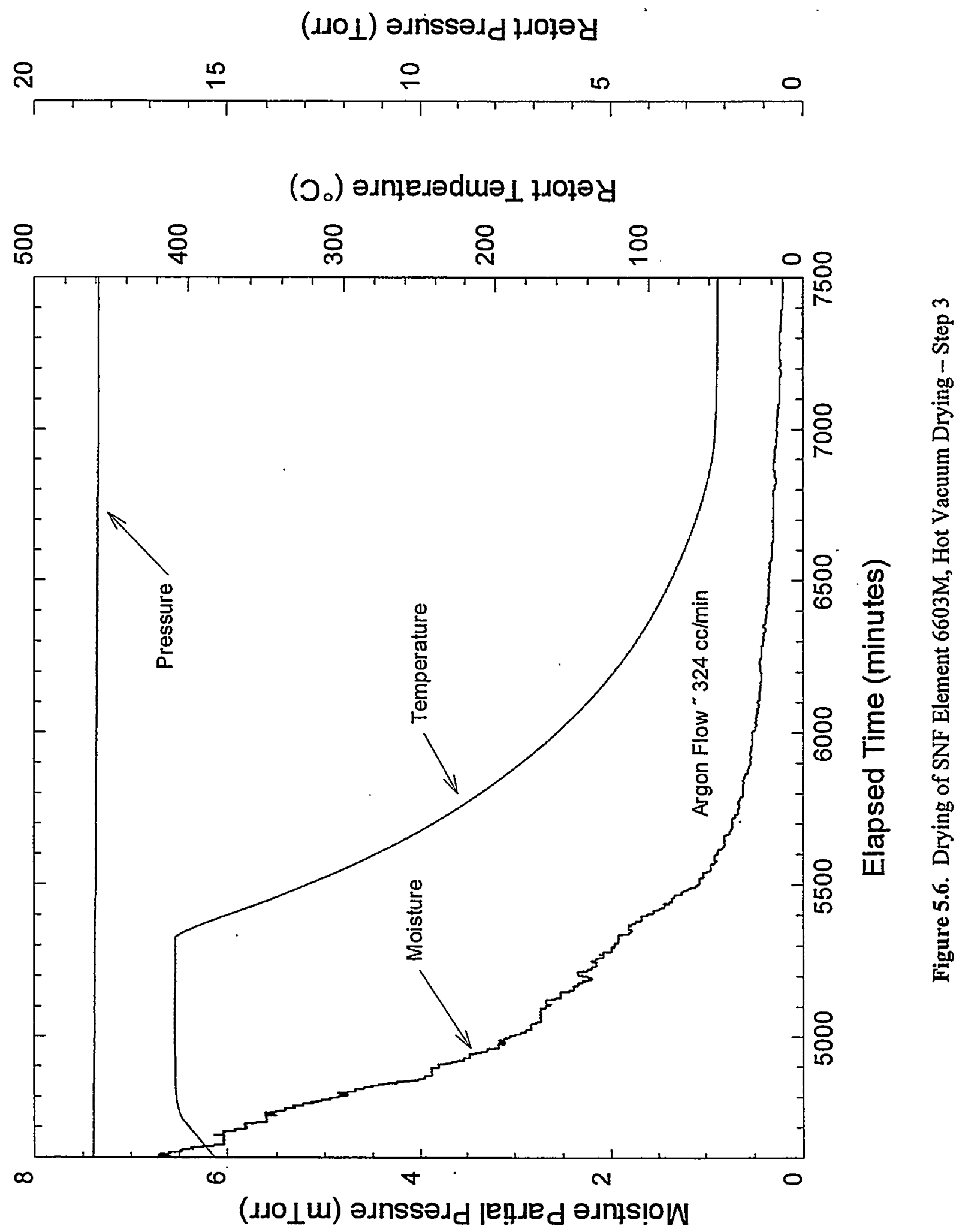

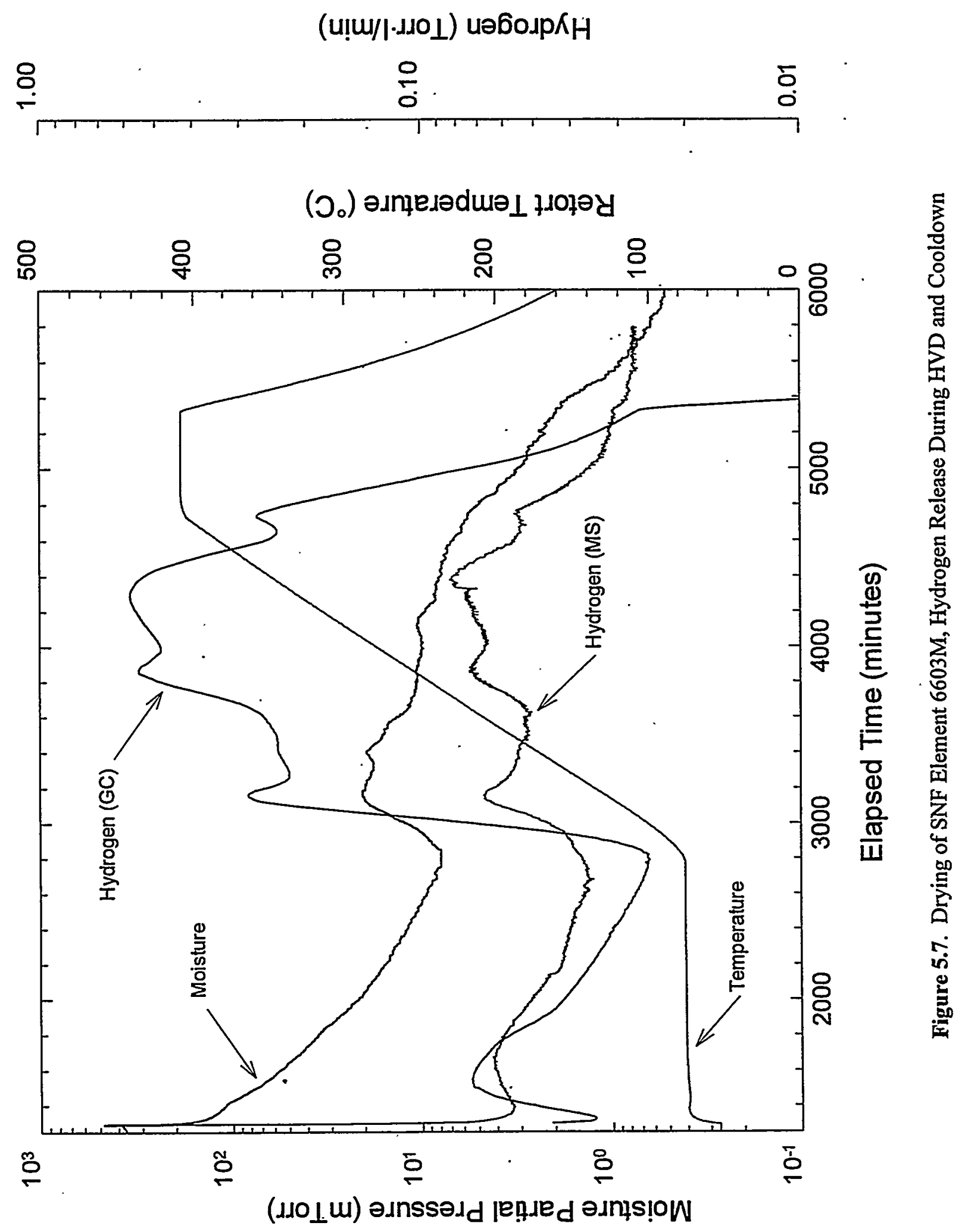
The initial increase in the hydrogen release during the early part of HVD-1 occurs while the water release was decreasing rapidly, suggesting that oxidation of the fuel element by water is just beginning to occur as the bulk of the fuel element reaches $75^{\circ} \mathrm{C}$. The correlation between the hydrogen and water signals during the latter part of HVD-1 suggests that the oxidation at this point is controlled by the availability of water.

The $127^{\circ} \mathrm{C}$ and $167^{\circ} \mathrm{C}$ peaks correlate closely with water releases at the same time and are likely due to oxidation of the fuel by water. Approximately 182 Torr $1(20 \mathrm{mg})$ of hydrogen were released during the same period as the water release peaks. The molar ratio of water to hydrogen released during the water release period (ET 2850 through 3700 ) is $\sim 0.4$. This implies that water is reacting with the fuel at a rate higher than it is being released into the vacuum (and thus swept away with the argon flow past the moisture sensor). It is likely that the hydrogen released during this period is due to oxidation of fuel by water released through oxy-hydrate decomposition in the corrosion regions or in isolated regions under the cladding.

The $253^{\circ} \mathrm{C}$ peak is most likely due to the decomposition of uranium hydride. This is further supported by the observation that there is no correlation with the water signal during this period, and also that this is close to the expected temperature for $\mathrm{UH}_{3}$ decomposition (Cotton 1988). Additionally, only a weak xenon release peak is observed at this time. This is consistent with the hypothesis that the decomposition of $\mathrm{UH}_{3}$ to uranium metal and hydrogen does not disrupt the crystal lattice of spent fuel matrix sufficiently to release all the interstitial xenon. This assumes the initial formation of $\mathrm{UH}_{3}$ in the fuel released most of the interstitial fission gases. Conversely, oxidation of the uranium metal does release xenon from the matrix. The quantity of hydrogen released due to $\mathrm{UH}_{3}$ decomposition is, therefore $\sim 61$ Torr $-1(6.6 \mathrm{mg})$, which equates to $\sim 0.6 \mathrm{~g}$ of $\mathrm{UH}_{3}$.

A larger broad peak occurring at $330^{\circ} \mathrm{C}$ is likely due to oxidation of uranium from a region in the fuel element under the cladding, which most likely split open during the temperature ramp during this time. Total integrated hydrogen release under this peak is $\sim 380$ Torr 1 ( $41 \mathrm{mg}$ ), representing the majority of the total hydrogen release. The negative "spike" in the hydrogen data just before the peak at $330^{\circ} \mathrm{C}$ (ET 4200) is regarded a "noise transient" and thus not included in the hydrogen release estimates. Similar peaks at $\sim 260^{\circ} \mathrm{C}$ and $300^{\circ} \mathrm{C}$ (and greater temperatures) were also observed in the hydrogen release for the previous two fuel elements 0309M (Run 3) and 5744U (Run 4). The total quantity of hydrogen released during HVD-2 (until just prior to $400^{\circ} \mathrm{C}$ ) was $\sim 712$ Torr $1(\sim 77 \mathrm{mg}$ ).

A small rise in the hydrogen release is also evident at a temperature close to $400^{\circ} \mathrm{C}$, however it is not clear whether this is a hydrogen release "peak" as this occurred at the end of the temperature ramp cycle. A similar rise was observed during the drying of Element 0309M (Run 3). Approximately 52 Torr 1 (6 mg) of hydrogen were released during the final phase of HVD.

\subsection{Mass Spectrometer Measurements}

The drying system was designed so that the Balzers Omnistar MS could be used in conjunction with the $G C$ to collect hydrogen and other gas release data over the test run. As is evident in Figure 5.8, the 
MS hydrogen signal showed the same general trends as the GC data, with the magnitude of the peaks being somewhat smaller. As has been observed in previous tests, this is likely due to differences in the calibration pressure for the MS and the actual pressures encountered in these drying tests. Two modifications are planned to resolve this issue: 1) replacement of the MS inlet pressure gauge with one that is more accurate in this low pressure range, and 2) recalibration of the MS at lower inlet pressures. These modifications will allow for more accurate normalization of the MS to actual sampling pressures. The sudden decrease in the hydrogen signal at 5300 ET corresponds with the start of the cooldown phase.

\subsubsection{Fission Gas Releases}

Fission gases such as xenon and krypton were also measured by the MS during the test. Monitoring of these gases can be useful in categorizing individual hydrogen releases as being from oxidation of uranium by water or decomposition of metal hydrides. Measured ${ }^{136}$ Xe releases during HVD are shown in Figure 5.9 along with the corresponding hydrogen and water release signals. For purposes of comparison, the ${ }^{136} \mathrm{Xe}$ data have been re-scaled and smoothed using a moving fourth-order polynomial procedure (Savitzky-Golay).

Xenon is released from the spent fuel matrix during oxidation, and to a much smaller extent during the thermal decomposition of $\mathrm{UH}_{3}$. As can be seen, the general trends in the xenon release match similar trends in both the water and hydrogen releases. Both the xenon and hydrogen releases show a broad peak during the isothermal phase of $\mathrm{HVD}$ at $\sim 80^{\circ} \mathrm{C}$. In addition, the xenon peaks at $\sim 3300 \mathrm{ET}, \sim 3900 \mathrm{ET}$, and $\sim 4200$ ET correspond closely with similar hydrogen and water release peaks, further supporting oxidation of the fuel by released moisture. Except for the broad peak at $1600 \mathrm{ET}$, the xenon peaks tend to be narrower than the hydrogen peaks, suggesting combined hydrogen release by more than one mechanism (hydride decomposition and fuel oxidation) or that the heavier fission gases are swept from the retort more quickly than hydrogen.

\subsubsection{ORIGEN2 Calculations}

It is also of interest to compare the magnitudes and isotopic composition of the various xenon isotopes released to that expected from fission product generation in the fuel. For this purpose, the ORIGEN2 computer code was used to calculate all stable and radioactive isotopes in both Mark 1A and Mark IV N-Reactor fuel (Schwarz 1997): Calculations were performed for ${ }^{240} \mathrm{Pu}$ levels ranging from 6 to $16 \%$ of plutonium in both types of fuel. For Mark IA fuel, this corresponds to exposures ranging from 1005 to $3619 \mathrm{MWD}$ at a power level of $10.05 \mathrm{MW}$. For Mark IV fuel, the exposures ranged from 811 to $2921 \mathrm{MWD}$ at a power level of 8.11 MW. Modifications were made to the nuclear cross-section libraries used by ORIGEN2 to improve the calculations for ${ }^{243} \mathrm{Am}$ and ${ }^{244} \mathrm{Cm}$. Calculations for the krypton and xenon isotopes are shown Table 5.2. Results are given in grams per metric ton of uranium which is equivalent to wppm. Total xenon varies from 172 to $754 \mathrm{wppm}$ for the various cases whereas total krypton is considerably lower at 14.5 to 57.5 wppm for the same reactor exposures. Figure 5.10 shows the relative concentration of xenon and krypton in hydrogen released as a function of burn-up dependency. 


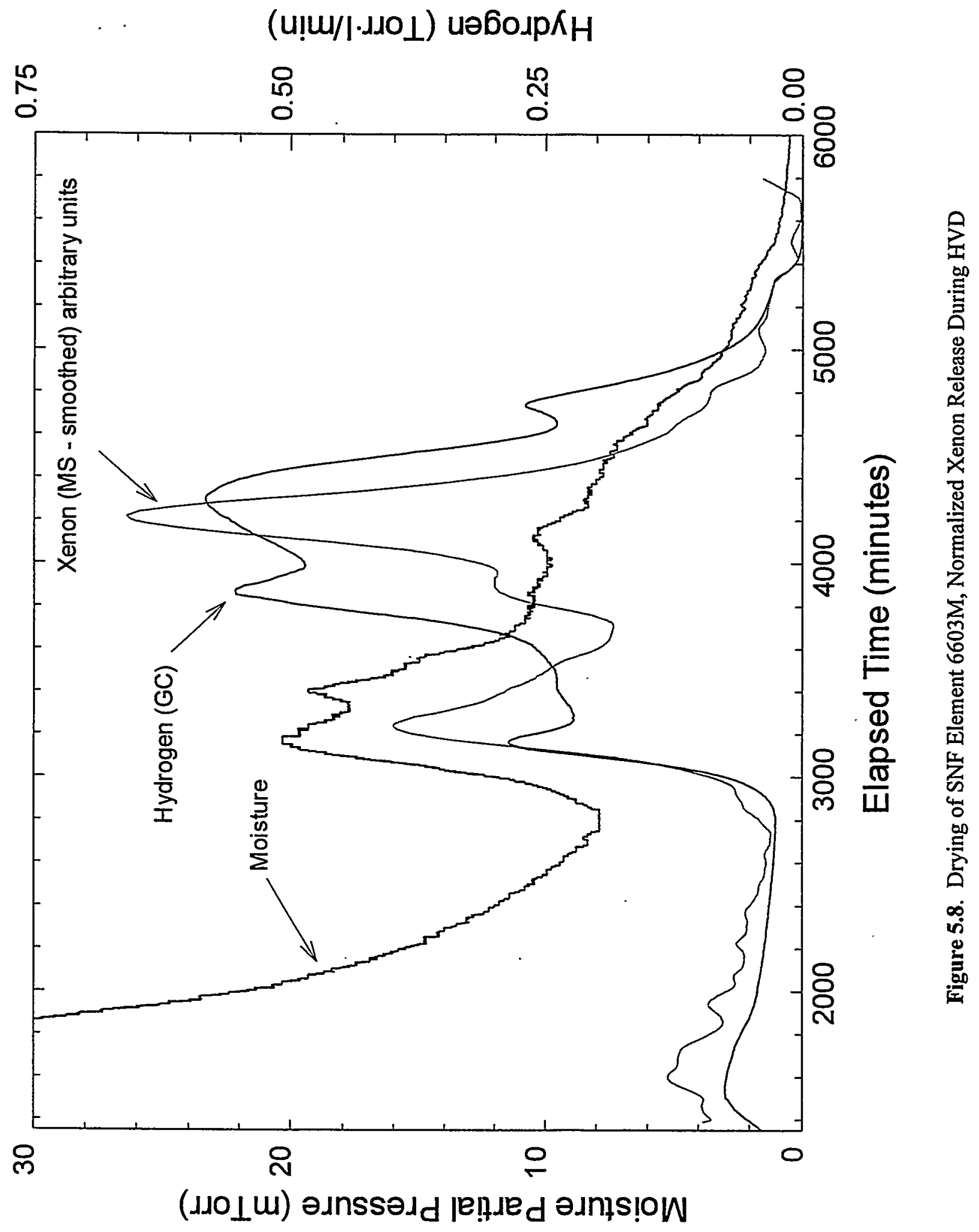


Table 5.2. Calculated Xenon Isotope Generation in Mark IA and IV N-Reactor Fuel (ORIGEN2)

\begin{tabular}{|c|c|c|c|c|c|c|c|c|}
\hline \multicolumn{9}{|c|}{ Mark IA N-Reactor Fuel } \\
\hline MWD & \multicolumn{2}{|c|}{1005.2} & \multicolumn{2}{|c|}{1674.6} & \multicolumn{2}{|c|}{2512.9} & \multicolumn{2}{|c|}{3618.6} \\
\hline Pu-240 & $6 \%$ & $\mathbf{W t} \%$ & $\mathbf{9 \%}$ & $\mathbf{W t} \%$ & $12 \%$ & wt\% & $16 \%$ & Wt\% \\
\hline $\mathrm{Kr}-80$ & 4.72E-06 & $0.00 \%$ & $9.54 E-06$ & $0.00 \%$ & $1.69 E-05$ & $0.00 \%$ & $2.78 E-04$ & $0.00 \%$ \\
\hline$K r-81$ & 1.67E-07 & $0.00 \%$ & 4.19E-07 & $0.00 \%$ & 8.57E-07 & $0.00 \%$ & $1.60 \mathrm{E}-06$ & $0.00 \%$ \\
\hline$K r-82$ & 4.59E-03 & $0.03 \%$ & 1.15E-02 & $0.04 \%$ & 2.39E-02 & $0.06 \%$ & 4.55E-04 & $0.00 \%$ \\
\hline$K r-83$ & $2.43 E+00$ & $13.76 \%$ & $3.89 E+00$ & $13.61 \%$ & $5.59 E+00$ & $13.43 \%$ & $7.58 E+00$ & $13.18 \%$ \\
\hline $\mathrm{Kr}-84$ & $4.79 E+00$ & $27.12 \%$ & $7.84 E+00$ & $27.44 \%$ & $1.16 E+01$ & $27.81 \%$ & $1.63 E+01$ & $28.31 \%$ \\
\hline$K r-85^{(a)}$ & $1.22 E+00$ & $6.91 \%$ & $1.97 E+00$ & $6.89 \%$ & $2.85 E+00$ & $6.84 \%$ & $3.90 E+00$ & $6.78 \%$ \\
\hline $\mathrm{Kr}-86$ & $9.22 E+00$ & $52.19 \%$ & $1.49 E+01$ & $52.03 \%$ & $2.16 E+01$ & $51.87 \%$ & $2.98 E+01$ & $51.73 \%$ \\
\hline Kr-Sum & 1.77E+01 & & $2.86 E+01$ & & $4.16 E+01$ & & $5.75 E+01$ & \\
\hline $\mathrm{Xe}-128$ & 5.02E-03 & $0.00 \%$ & $1.52 \mathrm{E}-02$ & $0.00 \%$ & $3.69 \mathrm{E}-02$ & $0.01 \%$ & $8.29 E-02$ & $0.01 \%$ \\
\hline $\mathrm{Xe}-129^{(b)}$ & $7.51 E-06$ & $0.00 \%$ & 1.83E-05 & $0.00 \%$ & 4.62E-05 & $0.00 \%$ & 1.24E-04 & $0.00 \%$ \\
\hline $\mathrm{Xe}-130$ & $2.94 \mathrm{E}-02$ & $0.01 \%$ & 8.21E-02 & $0.02 \%$ & $1.89 E-01$ & $0.04 \%$ & $4.02 E-01$ & $0.05 \%$ \\
\hline$X e-131$ & $2.26 E+01$ & $10.94 \%$ & $3.78 E+01$ & $10.92 \%$ & $5.63 E+01$ & $10.77 \%$ & $7.94 E+01$ & $10.53 \%$ \\
\hline $\mathrm{Xe}-132$ & $3.48 E+01$ & $16.86 \%$ & $5.93 E+01$ & $17.14 \%$ & $9.14 E+01$ & $17.47 \%$ & $1.35 E+02$ & $17.89 \%$ \\
\hline $\mathrm{Xe}-134$ & $5.93 E+01$ & $28.72 \%$ & $9.86 \mathrm{E}+01$ & $28.48 \%$ & $1.48 E+02$ & $28.29 \%$ & 2.12E+02 & $28.08 \%$ \\
\hline $\mathrm{Xe}-136$ & 8.97E+01 & $43.47 \%$ & $1.50 \mathrm{E}+02$ & $43.43 \%$ & 2.27E+02 & $43.43 \%$ & $3.28 E+02$ & $43.43 \%$ \\
\hline Xe-Sum & $2.06 E+02$ & & $3.46 E+02$ & & $5.23 E+02$ & & $7.54 \mathrm{E}+02$ & \\
\hline $1-127$ & $1.85 E+00$ & $22.29 \%$ & $3.26 \mathrm{E}+00$ & $22.66 \%$ & $5.19 E+00$ & $23.00 \%$ & $7.88 E+00$ & $23.37 \%$ \\
\hline $1-129$ & $6.43 E+00$ & $77.71 \%$ & $1.11 E+01$ & $77.34 \%$ & $1.74 E+01$ & $77.00 \%$ & $2.58 E+01$ & $76.63 \%$ \\
\hline I-Sum & $8.28 E+00$ & & $1.44 \mathrm{E}+01$ & & $2.26 E+01$ & & 3.37E+01 & \\
\hline \multicolumn{9}{|c|}{ Mark IV N-Reactor Fuel } \\
\hline MWD & 811.4 & & 1351.8 & & 2028.5 & & 2921.1 & \\
\hline Pu-240 & $6 \%$ & $\mathbf{W t} \%$ & $9 \%$ & $\mathbf{W t} \%$ & $12 \%$ & $\mathbf{W t} \%$ & $16 \%$ & $\mathbf{W t} \%$ \\
\hline $\mathrm{Kr}-80$ & 4.19E-06 & $0.00 \%$ & $8.53 E-06$ & $0.00 \%$ & 1.51E-05 & $0.00 \%$ & $2.49 E-05$ & $0.00 \%$ \\
\hline$K r-81$ & 1.61E-07 & $0.00 \%$ & 3.96E-07 & $0.00 \%$ & 8.03E-07 & $0.00 \%$ & $1.48 E-06$ & $0.00 \%$ \\
\hline $\mathrm{Kr}-82$ & 4.03E-03 & $0.03 \%$ & 9.99E-03 & $0.04 \%$ & 2.06E-02 & $0.06 \%$ & 3.92E-02 & $0.08 \%$ \\
\hline $\mathrm{Kr}-83$ & 2.01E+00 & $13.86 \%$ & $3.21 \mathrm{E}+00$ & $13.72 \%$ & $4.62 E+00$ & $13.57 \%$ & $6.27 E+00$ & $13.35 \%$ \\
\hline $\mathrm{Kr}-84$ & $3.94 E+00$ & $27.16 \%$ & $6.43 E+00$ & $27.49 \%$ & $9.48 E+00$ & $27.85 \%$ & $1.33 E+01$ & $28.32 \%$ \\
\hline $\mathrm{Kr}-85^{(\mathrm{a})}$ & 1.00E+00 & $6.89 \%$ & $1.61 E+00$ & $6.88 \%$ & $2.33 E+00$ & $6.84 \%$ & $3.18 E+00$ & $6.77 \%$ \\
\hline $\mathrm{Kr}-86$ & 7.55E+00 & $52.05 \%$ & $1.21 E+01$ & $51.86 \%$ & $1.76 E+01$ & $51.67 \%$ & $2.42 E+01$ & $51.48 \%$ \\
\hline Kr-Sum & $1.45 E+01$ & & $2.34 E+01$ & & $3.40 E+01$ & & $4.70 E+01$ & \\
\hline $\mathrm{Xe}-128$ & 4.37E-03 & $0.00 \%$ & 1.32E-02 & $0.00 \%$ & $3.20 \mathrm{E}-02$ & $0.01 \%$ & 7.14E-02 & $0.01 \%$ \\
\hline$X e-129^{(b)}$ & 6.89E-06 & $0.00 \%$ & 1.65E-05 & $0.00 \%$ & $4.07 \mathrm{E}-05$ & $0.00 \%$ & 1.07E-04 & $0.00 \%$ \\
\hline $\mathrm{Xe}-130$ & 2.55E-02 & $0.01 \%$ & 7.12E-02 & $0.02 \%$ & 1.63E-01 & $0.04 \%$ & 3.44E-01 & $0.05 \%$ \\
\hline Xe-131 & $1.90 \mathrm{E}+01$ & $11.03 \%$ & $3.19 E+01$ & $11.05 \%$ & $4.76 E+01$ & $10.91 \%$ & $6.72 E+01$ & $10.69 \%$ \\
\hline $\mathrm{Xe}-132$ & $2.92 E+01$ & $16.97 \%$ & $4.98 E+01$ & $17.26 \%$ & 7.68E+01 & $17.59 \%$ & $1.13 E+02$ & $18.01 \%$ \\
\hline Xe-134 & $4.93 E+01$ & $28.69 \%$ & $8.19 E+01$ & $28.41 \%$ & $1.23 E+02$ & $28.22 \%$ & 1.76E+02 & $28.01 \%$ \\
\hline $\mathrm{Xe}-136$ & $7.44 E+01$ & $43.29 \%$ & $1.25 E+02$ & $43.25 \%$ & $1.89 E+02$ & $43.23 \%$ & $2.72 E+02$ & $43.22 \%$ \\
\hline Xe-Sum & $1.72 E+02$ & & $2.88 E+02$ & & 4.37E+02 & & $6.29 E+02$ & \\
\hline $1-127$ & $1.64 \mathrm{E}+00$ & $22.87 \%$ & $2.90 E+00$ & $23.24 \%$ & $4.62 E+00$ & $23.54 \%$ & $7.00 \mathrm{E}+00$ & $23.88 \%$ \\
\hline $1-129$ & $5.52 \mathrm{E}+00$ & $77.13 \%$ & $9.58 E+00$ & $76.76 \%$ & $1.50 E+01$ & $76.46 \%$ & $2.23 E+01$ & $76.12 \%$ \\
\hline I-Sum & $7.15 E+00$ & & 1.25E+01 & & $1.96 E+01$ & & $2.93 E+01$ & \\
\hline
\end{tabular}




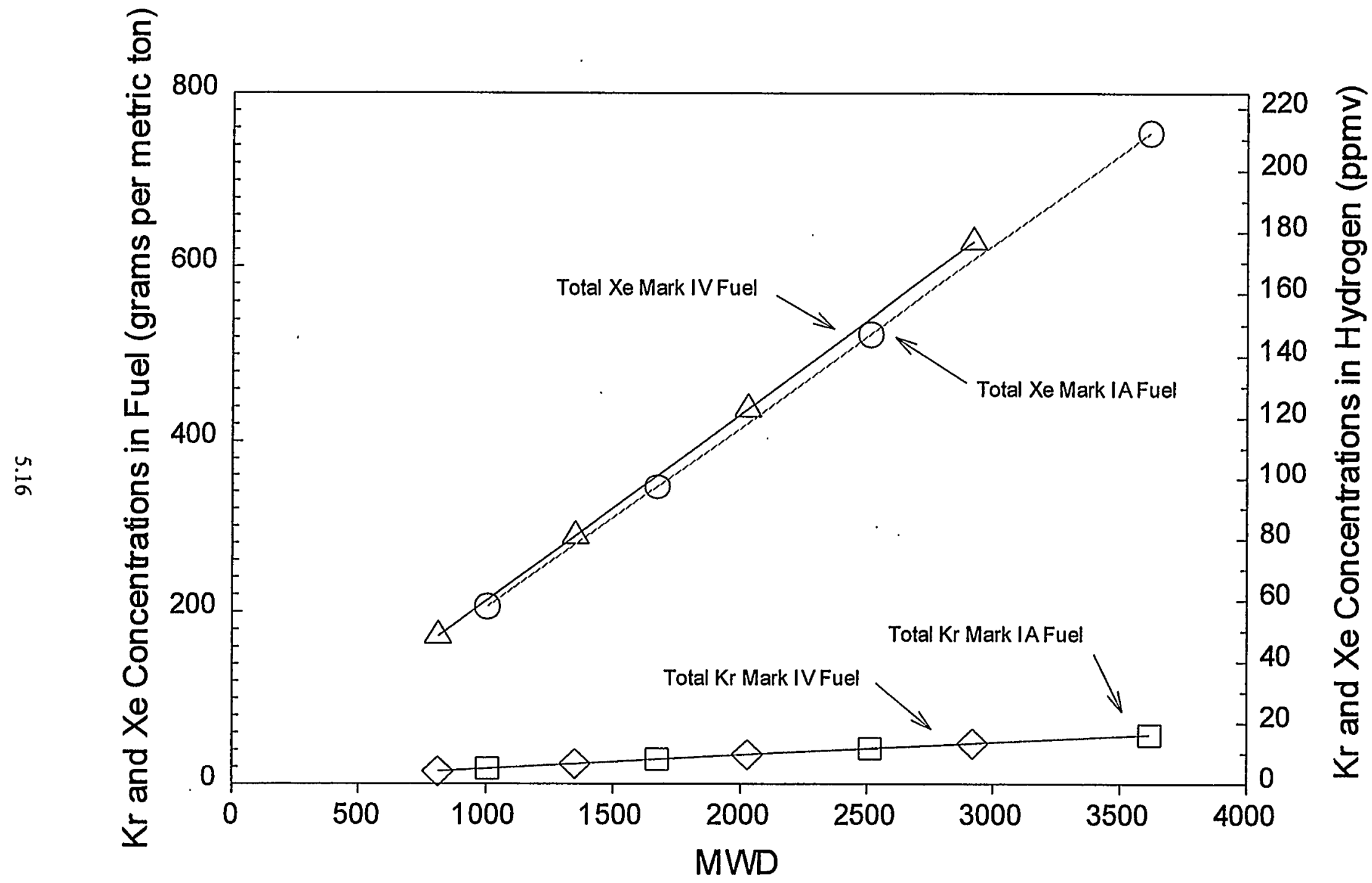

Figure 5.9. Concentrations of Krypton and Xenon in Hydrogen Released from Oxidation $\left(2 \mathrm{H}_{2} \mathrm{O}+\mathrm{U} \rightarrow \mathrm{UO}_{2}+2 \mathrm{H} 2\right)$ of Spent Fuel with $\mathrm{H}_{2} \mathrm{O}$ vs. Burn-up 
Krypton - Calculations for both types of fuel predict significant production of krypton isotopes at masses $82,83,84,85$, and 86 : Only very small quantities of ${ }^{80} \mathrm{Kr}$ and ${ }^{81} \mathrm{Kr}$ are produced. The relative amounts of each isotope show surprisingly little variation with increasing exposure. ${ }^{86} \mathrm{Kr}$ accounts for about $52 \mathrm{wt} \%$ of the total krypton with ${ }^{84} \mathrm{Kr}$ and ${ }^{83} \mathrm{Kr}$ at about $27 \mathrm{wt} \%$ and $14 \mathrm{wt} \%$, respectively. ${ }^{85} \mathrm{Kr}$ has a half-life of 10.76 years. At the end of each irradiation, the ${ }^{85} \mathrm{Kr}$ amounts to about $6.8 \mathrm{wt} \%$ of the krypton. However, this isotope will eventually decay to stable ${ }^{85} \mathrm{Rb}$, thereby increasing the relative amounts of the other krypton isotopes accordingly. For example, after 20 years, the ${ }^{85} \mathrm{Kr}$ would decrease from $6.8 \mathrm{wt} \%$ to about $1.9 \mathrm{wt} \%$ so that ${ }^{86} \mathrm{Kr}$ would then increase from $52 \mathrm{wt} \%$ to about $55 \mathrm{wt} \%$ with similar increases in the other remaining krypton isotopes. ${ }^{81} \mathrm{Kr}$ is also radioactive; however, the half-life is so long at $2.3 \mathrm{E}+5$ years that this effect is not important.

Xenon - Calculations for both types of fuel are quite similar and, as with krypton, the relative isotopic abundances show little variation with increasing exposure. The principal xenon isotopes produced are at masses $131,132,134$, and 136 . Only trace amounts of ${ }^{128} \mathrm{Xe}$ and ${ }^{130} \mathrm{Xe}$ are produced. In all cases, ${ }^{136} \mathrm{Xe}$ has the highest abundance at about $43 \mathrm{wt} \%$ with ${ }^{134} \mathrm{Xe},{ }^{132} \mathrm{Xe}$, and ${ }^{131} \mathrm{Xe}$ at about $29 \mathrm{wt} \%$, $17 \mathrm{wt} \%$, and $11 \mathrm{wt} \%$, respectively. ${ }^{129} \mathrm{Xe}$ is produced by the very slow decay of ${ }^{129} \mathrm{I}(1.57 \mathrm{E}+7$ years). This growth is so slow that the level of ${ }^{129} \mathrm{Xe}$ will remain negligible.

As with the krypton, the xenon isotopic fractions are relatively insensitive to fuel type and burnup. On average, the relative weight fraction of masses $131,132,134$, and 136 are $11 \%, 17 \%, 28 \%$, and $43 \%$, respectively. Figure 5.11 shows the MS data for masses 131,132,134, and 136 during the post-CVD pressure rise test. The slopes are standard error and are given in normalized signal units per minute since no absolute calibration was done for these specific xenon isotopes. This portion of the drying run had the largest xenon signals. The data have been normalized by the mass 138 data to compensate for small signal changes due to overall pressure variations in the MS detector. Regression fits to the xenon isotopic data are also shown in the figure along with the calculated regression slopes. Examination of the regression slopes yields relative xenon isotope release rates during the pressure rise test for masses 131 , 132,134 , and 136 , of $13 \%, 19 \%, 29 \%$, and $40 \%$, respectively. These values are very close to the . calculated percentages above, with an average $\mathrm{C} / \mathrm{E}$ (calculated-to-experimental) value of 0.94 , with the error probably due to uncertainties in the MS measurements. The standard errors for the four xenon MS signals are $\sim 3 \%$. 


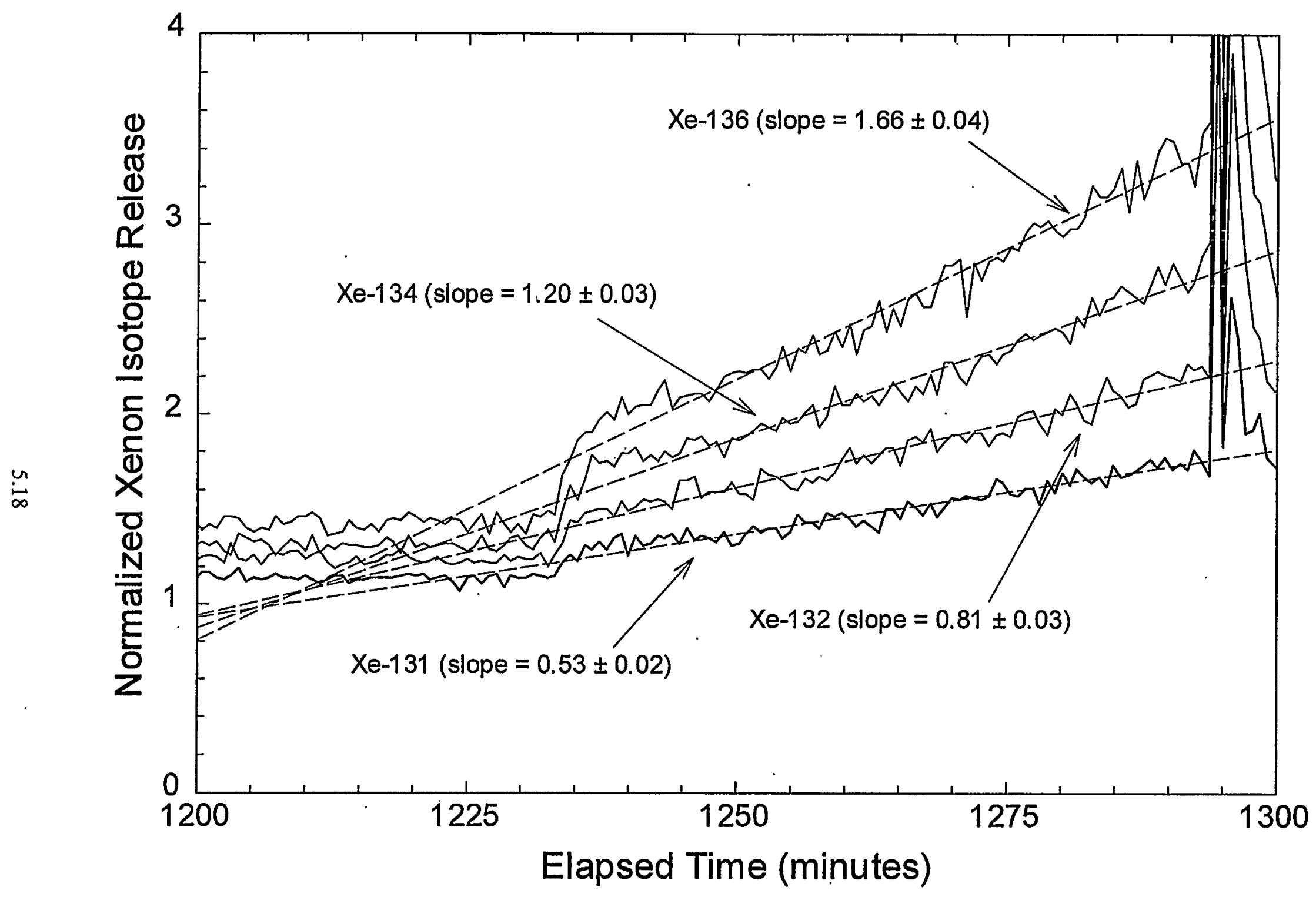

Figure 5.10. Drying of SNF Xenon Isotope Release During Post-CVE Pressure Rise Test 


\subsection{Discussion}

Approximately $4 \mathrm{ml}$ of water were observed in the condenser during the condenser pumpdown phase of CVD, in reasonable agreement with that calculated from the water release data over the same time period. An additional $\sim 0.4 \mathrm{mg}$ of water was removed during the post-CVD pressure rise test. As the temperature was only $\sim 50^{\circ} \mathrm{C}$, it is unlikely that metal oxy-hydrate decomposition was the source of this additional water. Therefore, this release can likely be interpreted as coming from free water that was trapped and not completely released during CVD. Similar to earlier tests, the source of the total pressure rise observed in the post-CVD test was only partially from residual moisture, suggesting that other sources of gas are responsible for some of the total pressure rise observed in the post-CVD test. The step appears to remove most of the free water.

During the first segment of HVD, approximately $0.9 \mathrm{~g}$ of water was removed at temperatures below $\sim 80^{\circ} \mathrm{C}$. The second phase of $\mathrm{HVD}$ released approximately $0.4 \mathrm{~g}$ of water with three main peaks at $\sim 130^{\circ} \mathrm{C}, \sim 173^{\circ} \mathrm{C}$, and $\sim 300^{\circ} \mathrm{C}$. The final phase of HVD at $400^{\circ} \mathrm{C}$ released only about $30 \mathrm{mg}$ of water, with an additional $\sim 21 \mathrm{mg}$ of water released during post-HVD cool-down. This indicates that small residual quantities of water remained even after the drying test was completed.

The water released after the post-CVD pressure rise test is attributed chiefly to the release of water from regions beneath the cladding and from under the corroded regions. Decomposition of metal oxyhydrates may also account for some of this water. The pre- and post-run visual examinations indicated the presence of a coating on the fuel element, which changed color during the test. Most of the water removal occurred during the first phase of HVD which entailed the temperature ramp from $\sim 50^{\circ} \mathrm{C}$ to $\sim 80^{\circ} \mathrm{C}$. The peaks in the moisture release during HVD-2 indicates water release from chemisorbed sites (i.e., hydrated species) at higher temperatures or from isolated areas such as beneath the corrosion or the cladding. Similar to the previous run, thermal decomposition of the hydrated species was not the most significant factor in controlling the removal of water from the system during the HVD. Rather, water released from the element from isolated regions along a "tortuous path" may be the controlling factor in post-CVD water removal. As observed in previous drying tests, a temperature above $400^{\circ} \mathrm{C}$ may be required for complete drying of the fuel element within a reasonable period of time.

Hydrogen data was obtained from the gas chromatograph during HVD when argon was flowing through the system. Hydrogen was first observed starting at the ramp-up to $\sim 80^{\circ} \mathrm{C}$, reaching a peak at $80^{\circ} \mathrm{C}$ before dropping. Approximately 66 Torr $1(7 \mathrm{mg})$ of hydrogen were released during HVD-1. Hydrogen release increased again during the ramp from $\sim 75^{\circ} \mathrm{C}$ to $\sim 400^{\circ} \mathrm{C}$, with four noticeable broad peaks at $\sim 127^{\circ} \mathrm{C}, \sim 159^{\circ} \mathrm{C}, \sim 253^{\circ} \mathrm{C}$, and $\sim 332^{\circ} \mathrm{C}$, the first of which roughly corresponds to a similar water release. The latter hydrogen release peak $(\sim 61 \mathrm{Torr} \cdot 1(6.6 \mathrm{mg}))$ at $\sim 256^{\circ} \mathrm{C}$ is due to uranium hydride decomposition, and is equivalent to $\sim 0.6 \mathrm{~g}$ of $\mathrm{UH}_{3}$ decomposed. Above $\sim 256^{\circ} \mathrm{C}$, the level of hydrogen began to increase with time, with $\sim 370$ Torr $\cdot 1(40 \mathrm{mg})$ of hydrogen released during HVD-3. Total hydrogen release during HVD was $\sim 770$ Torr $\cdot 1(\sim 83 \mathrm{mg})$. 
Hydrogen data collected by the MS showed the same general trends as the GC data, but with the magnitude of the peaks being smaller. Unfortunately, the pressure sensor at the inlet to the MS used to calculate the absolute hydrogen concentration was not accurate enough in the low range, hence the accuracy of the MS hydrogen data is somewhat poorer than the GC data. The MS inlet pressure sensor will be replaced with a more accurate sensor for future tests. Xenon data from the MS during HVD correlated well with corresponding water and hydrogen data, further supporting the argument that hydrogen release during HVD is due to a combination of oxidation of the fuel by released water, and by decomposition of metal hydrides. Xenon isotopic release data collected during the post-CVD pressure rise test showed excellent agreement with xenon isotopic ratios calculated for $\mathrm{N}$-Reactor fuel using the ORIGEN2 computer code. 


\subsection{References}

Cotton, F. A. 1988. Advanced Inorganic Chemistry. 5th Edition. John Wiley \& Sons, New York.

CRC Press. 1997. Handbook of Chemistry and Physics. 78th Edition. New York.

Lawrence, L. A. 1997. Strategy for Examination of the $15 \mathrm{~K}$-West Basin Fuel Elements. HNF-SD-SNFSP-018, DE\&S Hanford, Inc., Richland, Washington.

Ritter, G. A., S.C. Marchsman, P. J. MacFarlan, and D. A. King. 1998. Whole Element Furnace Testing System. PNNL-11807, Pacific Northwest National Laboratory, Richland, Washington.

Schwarz, R. A. 1997. Modification to ORIGEN2 for Generating N Reactor Source Terms.

PNNL-11555, Pacific Northwest National Laboratory, Richland, Washington.

Westinghouse Hanford Company (WHC). 1995. Hanford Spent Nuclear Fuel Project Integrated Process Strategy for K Basins Spent Nuclear Fuel. WHC-SD-SNF-SP-005, Rev. 0. 


\subsection{Supporting Documents and Related Reports}

Gerry, W. M. 1997a. Calibration of Mass Flow Controllers. SNF-TP-012, Rev. 0, Pacific Northwest National Laboratory, Richland, Washington.

Gerry, W. M. 1997b. Calibration of Balzer Quadstar Mass Spectrometer. SNF-TP-014, Rev. 0, Pacific Northwest National Laboratory, Richland, Washington.

Gerry, W. M. 1997c. Calibration of MTI Gas Chromatograph Model M200. SNF-TP-013, Rev. 0, Pacific Northwest National Laboratory, Richland, Washington.

Serles, J. A. 1997. Furnace Testing of N-Reactor Fuel Element 2660M. PTL-007, Rev. 0, Pacific Northwest National Laboratory, Richland, Washington.

Reports are written separately for the whole element drying test series as follows:

System Design Description for the Whole Element Furnace Testing System

Spent Fuel Drying System Test Results (First Dry-Run)

Spent Fuel Drying System Test Results (Second Dry-Run)

Spent Fuel Drying System Test Results (Dry-Run in Preparation for Run 8 [Third Dry-Run])

Drying Results of K-Basin Fuel Element 1990 (Run 1)

Drying Results of K-Basin Fuel Element 3128W (Run 2)

Drying Results of K-Basin Fuel Element 0309M (Run 3)

Drying Results of K-Basin Fuel Element 5744U (Run 4)

Drying Results of K-Basin Fuel Element 6603M (Run 5)

Drying Results of K-Basin Fuel Element 1164M (Run 6)

Drying Results of K-Basin Fuel Element 2660M (Run 7)

Drying Results of K-Basin Fuel Element 6513U (Run 8). 


\section{Distribution}

No. of

Copies

\section{OFFSITE}

C. L. Bendixsen

Idaho National Engineering and

Environmental Laboratory

P.O. Box 1625

Mail Stop 3135

Idaho Falls, ID 83415

A. W. Conklin

Washington State Department of Health

Airdustrial Park

Building 5, Mail Stop LE-13

Olympia, WA 98504-0095

M. A. Ebner

Idaho National Engineering and

Environmental Laboratory

P.O. Box 1625

Mail Stop 3114

Idaho Falls, ID 83415

A. R. Griffith

U.S. Department of Energy, Headquarters 19901 Germantown Rd (EM-65)

Germantown, MD 20585-1290

\section{T. J. Hull}

U.S. Department of Energy, Headquarters 19901 Germantown Road (EH-34)

Germantown, MD 20874-1290

M. R. Louthan

Savannah River Technology Center

Materials Technology Center

Aiken, SC 29808
No. of

Copies

T. E. Madey

Rutgers University

Bldg. 3865

136 Freylinghuysen $R d$

Piscataway, NJ 08854

B. K. Nelson

U.S. Department of Energy, Headquarters 19901 Germantown Road (EM-65)

Germantown, MD 20874-1290.

R. G. Pahl, Jr.

Argonne National Laboratory

P.O. Box 2528

Idaho Falls, ID 83403

R. S. Rosen

Lawrence Livermore National Laboratory 20201 Century Blvd., $1^{\text {ST }}$ Floor

Germantown, MD 20874

D. Silver

Washington State Department of Ecology

P.O. Box 47600

Olympia, WA 98504-7600

T. A. Thornton

Yucca Mountain Project M\&O Contractor SUM1/423

1261 Town Center Drive

Las Vegas, NV 89134

Distr.1 
No. of

Copies

ONSITE

B\&W Hanford

G. S. Barney

T5-12

5. DOE Richland Operations Office

R. M. Hiegel

S7-41

P. G. Loscoe

S7-41

C. R. Richins

J-S. Shuen

G. D. Trenchard

$6 \quad$ Numatec Hanford Company

G. P. Chevrier

T. Choho

E. R. Cramer

T. A. Flament

J. J. Irwin

C. R. Miska

23 Spent Nuclear Fuel Project

R. B. Baker

S. A. Chastain

$\mathrm{HO}-40$

D. R. Duncan

J. R. Frederickson

L. J. Garvin

E. W. Gerber

L. H. Goldmann

R3-11

R3-86
No. of

Copies

S. L. Hecht HO-40

L. A. Lawrence (5) H0-40

P. J. MacFarlan H0-40

B. J. Makenas H0-40

R. W. Rasmussen X3-85

J. A. Swenson R3-11

C. A. Thompson R3-86

D. J. Trimble H0-40

D. J. Watson X3-71

J. H. Wicks, Jr. X3-74

M. J. Wiemers R3-11

SNF Project Files

30 Pacific Northwest National Laboratory

J. Abrefah (5)

P7-27

J. P. Cowin

K8-88

S. R. Gano

K2-12

W. J. Gray

P7-27

L. R. Greenwood

P7-22

B. D. Hanson

P7-27

G. S. Klinger (3)

P7-22

D. K. Kreid

K7-80

P. J. MacFarlan

P7-27

S. C. Marschman (3)

P7-27

B. M. Oliver

P7-22

T. M. Orlando

K8-88

L. R. Pederson

$\mathrm{K} 2-44$

J. K. Tarantino

$\mathrm{K} 9-41$

J. C. Wiborg

K7-74

Information Release (7) 